\title{
Cloud-resolving chemistry simulation of a Hector thunderstorm
}

\author{
K. A. Cummings ${ }^{1}$, T. L. Huntemann ${ }^{1,{ }^{*}}$, K. E. Pickering ${ }^{2}$, M. C. Barth ${ }^{3}$, W. C. Skamarock ${ }^{3}$, H. Höller ${ }^{4}$, H.-D. Betz ${ }^{5}$, \\ A. Volz-Thomas ${ }^{6}$, and H. Schlager ${ }^{4}$ \\ ${ }^{1}$ Department of Atmospheric and Oceanic Science, University of Maryland, College Park, MD, USA \\ ${ }^{2}$ Atmospheric Chemistry and Dynamics Laboratory, NASA Goddard Space Flight Center, Greenbelt, MD, USA \\ ${ }^{3}$ NCAR Earth System Laboratory, National Center for Atmospheric Research, Boulder, CO, USA \\ ${ }^{4}$ Institut für Physik der Atmosphäre, Deutsches Zentrum für Luft- und Raumfahrt, Oberpfaffenhofen, Germany \\ ${ }^{5}$ Department of Physics, University of Munich, Munich, Germany \\ ${ }^{6}$ Institut für Chemie- und Klimaforschung, Forschungszentrum Jülich, Jülich, Germany \\ *now at: National Weather Service, Silver Spring, MD, USA
}

Correspondence to: K. A. Cummings (kristin@atmos.umd.edu)

Received: 30 April 2012 - Published in Atmos. Chem. Phys. Discuss.: 6 July 2012

Revised: 19 December 2012 - Accepted: 19 December 2012 - Published: 8 March 2013

\begin{abstract}
Cloud chemistry simulations were performed for a Hector thunderstorm observed on 16 November 2005 during the SCOUT-O3/ACTIVE campaigns based in Darwin, Australia, with the primary objective of estimating the average NO production per lightning flash in this unique storm type which occurred in a tropical island environment. The 3D WRF-Aqueous Chemistry (WRF-AqChem) model is used for these calculations and contains the WRF nonhydrostatic cloud-resolving model with online gas- and aqueous-phase chemistry and a lightning- $\mathrm{NO}_{\mathrm{x}}\left(\mathrm{LNO}_{\mathrm{x}}\right)$ production algorithm. The model was initialized by inducing convection with an idealized morning sounding and sensible heat source, and initial condition chemical profiles from merged aircraft observations in undisturbed air. Many features of the idealized model storm, such as storm size and peak radar reflectivity, were similar to the observed storm. Tracer species, such as $\mathrm{CO}$, used to evaluate convective transport in the simulated storm found vertical motion from the boundary layer to the anvil region was well represented in the model, with a small overestimate of enhanced $\mathrm{CO}$ at anvil altitudes. The lightning detection network (LINET) provided lightning flash data for the model and a lightning placement scheme injected the resulting NO into the simulated cloud. A lightning NO production scenario of 500 moles flash $^{-1}$ for both CG and IC flashes yielded anvil $\mathrm{NO}_{\mathrm{x}}$ mixing ratios that compared well with aircraft observations and were also similar to those deduced for several convective modeling analyses in the midlatitudes and subtropics. However, these NO production values were larger
\end{abstract}

than most estimates for tropical thunderstorms and given several uncertainties, $\mathrm{LNO}_{\mathrm{x}}$ production may have been as large as 600 moles flash $^{-1}$. Approximately $85 \%$ of the simulated $\mathrm{LNO}_{\mathrm{x}}$ mass was located above $7 \mathrm{~km}$ in the later stages of the storm, which was greater than amounts found for subtropical and midlatitude convection. Modeled upper tropospheric $\mathrm{NO}_{2}$ partial columns were also considerably greater than most satellite observations of tropical marine convective events, as tropical island convection, such as Hector, is more vigorous and more productive of $\mathrm{LNO}_{\mathrm{x}}$. Additional research is needed to investigate whether $\mathrm{LNO}_{\mathrm{x}}$ production per flash increases in storms with greater wind shear, such as this Hector storm, which showed significant variation in wind direction with altitude.

\section{Introduction}

Nitrogen oxides $\left(\mathrm{NO}_{\mathrm{x}}=\mathrm{NO}+\mathrm{NO}_{2}\right)$ are important trace gases in the troposphere due to their impact on photochemical ozone $\left(\mathrm{O}_{3}\right)$ formation. $\mathrm{NO}_{\mathrm{x}}$ also influences the $\mathrm{HO}_{\mathrm{x}}$ radicals $\left(\mathrm{HO}_{\mathrm{x}}=\mathrm{HO}+\mathrm{HO}_{2}\right)$, which are the main oxidant of numerous chemical species. Fossil fuel combustion, biomass burning, microbial activity in soils, and lightning are considered the four major sources of tropospheric $\mathrm{NO}_{\mathrm{x}}$. Lightning generates less $\mathrm{NO}_{\mathrm{x}}$ than anthropogenic sources, but does so mainly in the middle and upper troposphere where $\mathrm{NO}_{\mathrm{x}}$ is longer-lived and more efficient at producing $\mathrm{O}_{3}$ than

Published by Copernicus Publications on behalf of the European Geosciences Union. 
in the boundary layer where much of the anthropogenic $\mathrm{NO}_{\mathrm{x}}$ is emitted. The best estimate of the global lightninggenerated $\mathrm{NO}_{\mathrm{x}}\left(\mathrm{LNO}_{\mathrm{x}}\right)$ source is $5 \pm 3 \mathrm{Tg} \mathrm{N} \mathrm{yr}^{-1}$ (Schumann and Huntrieser, 2007). The uncertainty in the source strength is due to both an uncertainty in the total number of flashes globally and the amount of $\mathrm{NO}_{\mathrm{x}}$ per flash or per meter of flash length. The issue is further complicated because cloud-to-ground (CG) flashes and intracloud (IC) flashes may produce different amounts of $\mathrm{NO}_{\mathrm{x}}$. Schumann and Huntrieser (2007) provide a detailed review of three decades of research on the global $\mathrm{LNO}_{\mathrm{x}}$ source rate.

One method used in estimating $\mathrm{NO}_{\mathrm{x}}$ production per flash is through application of cloud-resolving models. Most of these simulations focused on midlatitude and subtropical convective systems. Midlatitude convection primarily occurs in the $35-45^{\circ}$ latitude belt in both hemispheres, often associated with synoptic-scale weather systems. Subtropical and tropical convection is found closer to the equator, away from the influence of midlatitude systems, and is differentiated based on development within air masses of lower and higher equivalent potential temperatures, respectively (Huntrieser et al., 2007). Attention is now turning to data from several atmospheric chemistry field programs recently conducted in tropical convective environments. We focus here on the simulation of a Hector thunderstorm observed on 16 November 2005 during the Stratospheric-Climate Links with Emphasis on the Upper Troposphere and Lower Stratosphere (SCOUTO3; Brunner et al., 2009) and Aerosol and Chemical Transport in Tropical Convection (ACTIVE; Vaughan et al., 2008) field experiments based in Darwin, Australia. The name Hector is given to the very deep convective storms which develop over the Tiwi Islands offshore from Darwin, particularly during the transition season (November-December) prior to the monsoon onset.

Deep convection has important effects on atmospheric chemistry, which include the rapid redistribution of chemical constituents from the boundary layer to the upper troposphere (Chatfield and Crutzen, 1984; Dickerson et al., 1987). Here lower temperatures slow reaction rates, which generally allows chemical species in the upper troposphere to have longer lifetimes and therefore be transported globally. Chemical consequences of the transport of boundary layer air to the upper troposphere can include changes in water vapor that lead to changes in $\mathrm{HO}_{\mathrm{x}}$, as well as changes in $\mathrm{O}_{3}$ (Pickering et al., 1990, 1992) and precursors. Over most of the tropics, low mixing ratios of $\mathrm{O}_{3}$ and $\mathrm{NO}_{\mathrm{x}}$ are transported to the tropical tropopause layer (Pickering et al., 1993; Wang and Prinn, 2000; Salzmann et al., 2008) except over polluted areas, such as urban centers and biomass burning regions. Other chemical consequences include changes in aerosol concentrations and the aforementioned $\mathrm{LNO}_{\mathrm{x}}$ production and transport. Thunderstorms inject $\mathrm{NO}_{\mathrm{x}}$ from lightning into the middle and upper troposphere. Over relatively unpolluted regions of the tropics, $\mathrm{LNO}_{\mathrm{x}}$ can be the dominant chemical effect of deep convection. Along with enhanced $\mathrm{HO}_{\mathrm{x}}$ in the upper tro- posphere, $\mathrm{LNO}_{\mathrm{x}}$ leads to efficient $\mathrm{O}_{3}$ production in this layer of up to several ppbv per day (DeCaria et al., 2005). Ozone, the third most important greenhouse gas, is most effective in this role in the upper troposphere and lower stratosphere (IPCC, 2007). Therefore, better knowledge of $\mathrm{LNO}_{\mathrm{x}}$ production is important for the understanding of climate forcing. Cloud-resolving models with chemistry, after evaluation with field observations, can be used to better understand convective transport processes and $\mathrm{LNO}_{\mathrm{x}}$ production. Cloud-scale models are valuable because they can simulate the transport and distribution of $\mathrm{NO}_{\mathrm{x}}$ and its contribution to photochemistry at scales directly comparable to airborne observations in thunderstorms (Schumann and Huntrieser, 2007).

This study provides the first analysis of a cloud-resolved $\mathrm{LNO}_{\mathrm{x}}$ simulation of deep convection in the tropics for which detailed lightning flash data and anvil $\mathrm{NO}_{\mathrm{x}}$ measurements are available. The primary objective is to estimate the average production of NO per lightning flash in a tropical environment. However, tropical island convection, like Hector thunderstorms, may not be representative of other types of convection found in the tropics. Section 2 reviews selected $\mathrm{LNO}_{\mathrm{x}}$ cloud-resolved simulations, analysis of results from airborne tropical $\mathrm{LNO}_{\mathrm{x}}$ experiments, and numerical modeling studies of tropical thunderstorms over the Maritime Continent. Section 3 describes the ground-based and aircraft observations of the Hector thunderstorm. Section 4 provides a description of the Weather Research and Forecasting Aqueous Chemistry (WRF-AqChem) model and initialization data. Section 5 compares the meteorological and chemical features of the observed and simulated thunderstorm, and Sect. 6 presents the conclusions from our cloud-resolved tropical island convection simulation.

\section{Background}

\subsection{Lightning-produced $\mathrm{NO}_{\mathrm{x}}$ in cloud-resolving models}

To simulate $\mathrm{LNO}_{\mathrm{x}}$ production, the flash rate, type of flash, NO source location, and amount of NO produced must be represented. Flash rates can either be predicted from storm parameters, such as cloud top height, maximum vertical velocity, ice mass fluxes, and updraft volume (Price and Rind, 1992; Petersen et al., 2005; Deierling and Petersen, 2008; Deierling et al., 2008; Barthe et al., 2010) or, to reduce uncertainty, prescribed directly from lightning observations (DeCaria et al., 2005; Ott et al., 2010). Likewise, the flash type can be predicted (Price and Rind, 1993; Pickering et al., 1998; Fehr et al., 2004) or prescribed from observations (DeCaria et al., 2005; Ott et al., 2007, 2010). The NO source location is generally near the storm core, but can reach several tens of kilometers away (Höller et al., 2009; Kuhlman et al., 2009). In the volumetric approach to parameterizing $\mathrm{LNO}_{\mathrm{x}}$, the DeCaria et al. $(2000,2005)$ scheme uses the $20 \mathrm{dBZ}$ reflectivity contour as the threshold for the 
Table 1. Summary of cloud-resolved simulations of $\mathrm{LNO}_{\mathrm{x}}$ production.

\begin{tabular}{|c|c|c|c|c|c|}
\hline Model & $\begin{array}{l}\text { Moles NO per } \\
\text { CG flash }\end{array}$ & $P_{\mathrm{IC}} / P_{\mathrm{CG}}$ & Field Campaign & Region & Reference \\
\hline 2-D GCE & $200-500$ & $>0.5$ & STERAO-A & Midlatitude & DeCaria et al. (2000) \\
\hline 3-D GCE/CSCTM & 460 & $0.75-1.00$ & STERAO-A & Midlatitude & DeCaria et al. (2005) \\
\hline MM5 & 330 & 1.4 & EULINOX & Midlatitude & Fehr et al. (2004) \\
\hline 3-D GCE/CSCTM & 360 & 1.15 & EULINOX & Midlatitude & Ott et al. (2007) \\
\hline 3-D GCE/MM5/CSCTM & $500^{1}$ & $0.94^{1}$ & $\begin{array}{l}\text { STERAO-A; } \\
\text { EULINOX; } \\
\text { CRYSTAL-FACE }\end{array}$ & $\begin{array}{l}3 \text { midlatitude; } \\
2 \text { subtropical }\end{array}$ & Ott et al. (2010) \\
\hline Intercomparison $^{2}$ & $36-465$ & $\sim 0.1-1.0$ & STERAO-A & Midlatitude & Barth et al. (2007b) \\
\hline
\end{tabular}

horizontal within-cloud placement of $\mathrm{LNO}_{\mathrm{x}}$. Ott et al. (2007) devised a different $\mathrm{LNO}_{\mathrm{x}}$ placement scheme where the resulting NO production tries to better mimic lightning flash channels through a filamentary approach (Barthe and Barth, 2008; Ott et al., 2010). This approach uses a smaller source location, which represents NO production per flash or per meter flash length. NO production per flash can be derived from model results through comparisons with aircraft storm anvil measurements.

Cloud-scale simulations have used various models to estimate NO production per flash and the $P_{\mathrm{IC}} / P_{\mathrm{CG}}$ ratio, where $P_{\mathrm{IC}}$ and $P_{\mathrm{CG}}$ are the mean NO production per IC and CG flash, respectively. Table 1 provides a list of the model types, as well as the $\mathrm{LNO}_{\mathrm{x}}$ production results from each cloud-resolved simulation. For all simulated storms, the $\mathrm{LNO}_{\mathrm{x}}$ was compared against aircraft $\mathrm{NO}_{\mathrm{x}}$ observations in the anvils to deduce $P_{\mathrm{IC}}$ and $P_{\mathrm{CG}}$. With the cloud-resolved two-dimensional (2-D) Goddard Cumulus Ensemble (GCE) model, Pickering et al. (1998) parameterized the $\mathrm{LNO}_{\mathrm{x}}$ source by uniformly distributing individual flashes in the vertical within separate $\mathrm{CG}$ and IC lightning regions, where flash rates were predicted based on updraft vertical velocity. Seven convective events from three different regimes (midlatitude continental, tropical continental, and tropical marine) were simulated using the algorithm, and the resulting C-shaped $\mathrm{LNO}_{\mathrm{x}}$ vertical profiles were developed for use in larger scale models. DeCaria et al. (2000, 2005) modified the Pickering et al. (1998) scheme by assuming a more physically realistic non-uniform distribution of lightning channels and using observed IC and CG flash rates. The flash channel vertical modes, as well as $\mathrm{NO}_{\mathrm{x}}$ production, followed Gaussian distributions. This general technique has also been used by Ott et al. $(2007,2010)$ in simulating a series of midlatitude and subtropical thunderstorms. The assumptions that $P_{\mathrm{CG}}$ was roughly 460 moles NO flash ${ }^{-1}$ and $P_{\text {IC }}$ was $75-100 \%$ of
$P_{\mathrm{CG}}$ (DeCaria et al., 2005) provided the best comparison to the column $\mathrm{NO}_{\mathrm{x}}$ mass computed from aircraft observations for the 12 July 1996 Stratosphere-Troposphere Experiment: Radiation, Aerosols and Ozone (STERAO-A) storm. Fehr et al. (2004) and Ott et al. (2007) both studied the production of $\mathrm{LNO}_{\mathrm{x}}$ in the midlatitude 21 July European Lightning Nitrogen Oxides Project (EULINOX) storm using different models. Similar results for $P_{\mathrm{CG}}$ were obtained and both simulations showed an IC flash produced more $\mathrm{LNO}_{\mathrm{x}}$ than a CG flash. Ott et al. (2010) has summarized the $\mathrm{LNO}_{\mathrm{x}}$ production results from five 3-D midlatitude and subtropical storm simulations. Mean production per CG flash over the five storms was 500 moles flash $^{-1}$ with a mean $P_{\mathrm{IC}} / P_{\mathrm{CG}}$ ratio of 0.94 .

Explicit electrical schemes have been used by Zhang et al. (2003b) and Barthe et al. (2007) to study $\mathrm{LNO}_{\mathrm{x}}$. A small, isolated, short-lived 19 July 1989 Cooperative Convective Precipitation Experiment (CCOPE) cloud with simple chemistry was simulated using the Storm Electrification Model (SEM) (Zhang et al., 2003a, b). In general, the results indicated the parameterization produced $\mathrm{NO}$ mixing ratios comparable to observations with a maximum $\mathrm{LNO}_{\mathrm{x}}$ mixing ratio of 35.8 ppbv. Barthe et al. (2007) tested an explicit electrical scheme for $\mathrm{LNO}_{\mathrm{x}}$ using the 10 July 1996 STERAO storm. Lightning flash frequency and total path length were the key factors determined by the simulated electrical state of the storm. $\mathrm{LNO}_{\mathrm{x}}$ dominated the $\mathrm{NO}_{\mathrm{x}}$ budget in the upper portion of the cells with instantaneous peak mixing ratios exceeding $4 \mathrm{ppbv}$ in accordance with observations. Estimated NO production was 36 moles flash $^{-1}$.

The cloud-scale model intercomparison performed by Barth et al. (2007b) showed intermodel variability was much larger for simulated $\mathrm{NO}_{\mathrm{x}}$ than the chemical tracers, $\mathrm{CO}$ and $\mathrm{O}_{3}$, demonstrating the uncertainty surrounding the $\mathrm{NO}$ source placement and its volume within the storm, as each model used a different method. A wide range of $\mathrm{LNO}_{\mathrm{x}}$ 
production rates (36-465 moles flash ${ }^{-1}$ ) was noted when six different models were used, yet similar $\mathrm{NO}_{\mathrm{x}}$ mixing ratios were obtained in the anvil region. This result, as well as the information gained from using explicit electrification schemes, indicated there is still much to learn about $\mathrm{LNO}_{\mathrm{x}}$ production in thunderstorms. One model used in the intercomparison was the WRF-AqChem model by Barth et al. (2007a), which inputs observed flash rates for $\mathrm{LNO}_{\mathrm{x}}$ parameterization, similar to DeCaria et al. (2005). The results indicated it was unlikely lightning affects concentrations of $\mathrm{HO}_{\mathrm{x}}$ precursors near active convection.

Based on the simulations run by Ott et al. (2010), application of their $\mathrm{LNO}_{\mathrm{x}}$ production rates $\left(500\right.$ moles flash $\left.{ }^{-1}\right)$ with the global annual average flash rate of 44 flashes s $^{-1}$ yielded an annual global $\mathrm{LNO}_{\mathrm{x}}$ production of about $9 \mathrm{Tg} \mathrm{N} \mathrm{yr}^{-1}$, which was significantly larger than the $5 \mathrm{Tg} \mathrm{N} \mathrm{yr}^{-1}$ estimated by Schumann and Huntrieser (2007). This raises the question as to whether lightning flashes in tropical thunderstorms produce less $\mathrm{NO}_{\mathrm{x}}$ on average than flashes in midlatitude or subtropical storms. In this paper, we test whether a NO production scenario of 500 moles flash $^{-1}$ for both IC and CG flashes generates model-simulated $\mathrm{NO}_{\mathrm{x}}$ mixing ratios similar to those observed in a Hector thunderstorm.

\section{2 $\mathrm{LNO}_{\mathrm{x}}$ production in tropical thunderstorms}

Wind shear is useful not only as a proxy for ice mass or volume, since it relates to storm dynamics and updraft size (Huntrieser et al., 2008, 2009, 2011), but also for assessing flash length and associated $\mathrm{NO}_{\mathrm{x}}$ production in different climate regimes. As lightning activity is physically related to ice mass aloft, it is also associated with environmental shear, as storms grow larger (and contain larger amounts of ice mass) under stronger shear. Huntrieser et al. (2008) hypothesized a tropical flash may produce, on average, less NO than a flash in a midlatitude or subtropical storm because weaker vertical wind shear in the tropics leads to shorter flash channel lengths. If the amount of nitrogen produced by lightning is better correlated with flash channel lengths than the number of strokes, subtropical and midlatitude storms may have a significant impact on global $\mathrm{LNO}_{\mathrm{x}}$ even though the majority of global lightning occurs in the tropics.

Several tropical field campaigns have been conducted in an attempt to further investigate regional $\mathrm{LNO}_{\mathrm{x}}$ production rates and their impact on global $\mathrm{LNO}_{\mathrm{x}}$. The first aircraft experiment specifically designed to estimate $\mathrm{LNO}_{x}$ production in the tropics was the Biomass Burning and Lightning Experiment (BIBLE-C) based in Darwin, Australia (Koike et al., 2007). On two flights, enhanced upper tropospheric $\mathrm{NO}_{\mathrm{x}}$ mixing ratios were attributed to lightning located several hundred kilometers upstream near the Gulf of Carpentaria. Observed lightning data and a $\mathrm{LNO}_{\mathrm{x}}$ vertical distribution (Pickering et al., 1998) were used in conjunction with aircraft $\mathrm{NO}_{\mathrm{x}}$ observations to estimate $\mathrm{LNO}_{\mathrm{x}}$ production rates of 3173 moles flash $^{-1}$ for one storm and 348-813 moles flash $^{-1}$ in a second system. Based on the Tropical Convection, Cirrus, and Nitrogen Oxides Experiment (TROCCINOX) in Brazil, the $\mathrm{LNO}_{\mathrm{x}}$ mass production for tropical thunderstorms was of similar magnitude as that found for one of the BIBLEC storms $\left(\sim 70\right.$ moles flash $\left.^{-1}\right)$, while a subtropical thunderstorm also analyzed during the campaign had a production rate of $\sim 140-210$ moles flash $^{-1}$ (Huntrieser et al., 2008).

Huntrieser et al. (2009) analyzed thunderstorms sampled over Northern Australia during the SCOUT-O3/ACTIVE field experiment with results similar to the Brazilian thunderstorms. On 19 November 2005, tropical continental thunderstorms generated lower $\mathrm{LNO}_{\mathrm{x}}$ production rates (121 moles flash ${ }^{-1}$ ) compared with subtropical continental (385 moles flash ${ }^{-1}$ ) and Hector (292-343 moles flash $^{-1}$ ) thunderstorms. Like the thunderstorms observed during TROCCINOX, the estimated vertical wind shear over Northern Australia between the anvil outflow and steering level was greater in subtropical $\left(\sim 15 \mathrm{~m} \mathrm{~s}^{-1}\right)$ versus tropical $\left(\sim 6 \mathrm{~m} \mathrm{~s}^{-1}\right)$ convection. For Hector thunderstorms a different process may be responsible, where the presence of multiple storm centers from merging convective cells may lead to longer flash lengths. The premonsoon season flight discussed by Huntrieser et al. (2009), measured enhanced upper tropospheric $\mathrm{NO}_{\mathrm{x}}$ only within storm systems (Labrador et al., 2009), while later in the ACTIVE experiment (e.g., January 2006) enhancements in $\mathrm{LNO}_{\mathrm{x}}$ were found over widespread regions.

Mesoscale convective systems (MCSs) over West Africa were analyzed during the African Monsoon Multidisciplinary Analysis (AMMA) wet season field campaign (Huntrieser et al., 2011). Unlike the Brazilian (Huntrieser et al., 2008) and Australian (Huntrieser et al., 2009) thunderstorms, the AMMA MCSs showed a greater influence from boundary layer versus lightning $\mathrm{NO}_{\mathrm{x}}$. The tropical and subtropical MCSs investigated during AMMA indicated $\mathrm{LNO}_{\mathrm{x}}$ production rates ( 70 moles flash $^{-1}$ and 179 moles flash $^{-1}$, respectively) were comparable to those observed in similar air mass thunderstorms during TROCCINOX. Unlike the tropical and subtropical thunderstorms observed during TROCCINOX and SCOUT-O3/ACTIVE, the difference in vertical wind shear (defined as the difference between the anvil outflow and steering level wind vectors) between subtropical and tropical AMMA MCSs was not as large $\left(7 \mathrm{~m} \mathrm{~s}^{-1}\right.$ and $9 \mathrm{~m} \mathrm{~s}^{-1}$, respectively).

Based on the results from the tropical field campaigns, thunderstorms closer to the equator generally have lower $\mathrm{LNO}_{\mathrm{x}}$ production rates, and convection over Northern Australia tend to exhibit higher production rates than storms observed in Brazil and West Africa (Höller et al., 2009). Although previous research has characterized thunderstorms based on the type of air mass in which the cell developed (e.g., tropical air mass) and not by the geographic location, it is important to note that storms that evolve over the same area (e.g., tropical northern Australia) cannot be placed into one specific category of convection, as 
thunderstorms may develop within different climate regimes over the same location. May and Ballinger (2007) point out the differences in convection near Darwin, Australia, during the buildup/break and monsoonal regimes. Storms that occur in the buildup/break regime are representative of continental tropical convection and are generally tall, small in size, long-lived, and intense. The opposite is true of thunderstorms during the monsoon season, which are considered more maritime tropical, even though they occur over the same geographic area. Therefore, an investigation of a greater variety of storm types and environmental conditions would provide additional estimates of $\mathrm{LNO}_{\mathrm{x}}$ production rates and help reduce the large uncertainty that still exists for estimating and modeling the global $\mathrm{LNO}_{\mathrm{x}}$ production rate. Labrador et al. (2005) highlight this need while investigating a "best" source magnitude and vertical placement of $\mathrm{LNO}_{\mathrm{x}}$. It is indicated the uncertainty also lies in a lack of understanding the amount of energy, and associated NO molecules, produced per lightning discharge, as well as the horizontal distribution of lightning.

The in-situ measurements made during SCOUTO3/ACTIVE over the "Maritime Continent" (the Indonesian archipelago, north Australia, and New Guinea) are well-suited for studying $\mathrm{LNO}_{\mathrm{x}}$ with a cloud-resolving model. Previous modeling studies indicate the feasibility of incorporating observations into numerical thunderstorm simulations in this region. This leads to consideration of how NO production per flash in a Hector storm compares with those at higher latitudes and with other storm types in the tropics. This paper contains the first cloud-resolved $\mathrm{LNO}_{\mathrm{x}}$ simulation performed in the deep tropics for a storm with detailed lightning and anvil $\mathrm{NO}_{\mathrm{x}}$ observations.

\subsection{Numerical simulations of Hector thunderstorms}

The "Maritime Continent" is one of the primary regions of global latent heat release that contributes to the forcing of the planetary-scale Hadley and Walker circulations. Global climate variations are directly influenced by changes in latent heat release and radiative heating within this region. During the transition season (November-December), characteristic diurnal convection is detected on $65-90 \%$ of days over a pair of relatively flat islands, called the Tiwis, north of Darwin, Australia (Saito et al., 2001). Together the Tiwi Islands (Fig. 1) are about $150 \mathrm{~km}$ west-to-east and $50 \mathrm{~km}$ north-tosouth (Crook, 2001). The islands are excellent laboratories for studying geographically fixed tropical convection due to their diurnal cycle of latent heat release. The storms, locally known as Hector, can reach heights of $20 \mathrm{~km}$, allowing them to be viewed from locations, like Darwin, that are $100 \mathrm{~km}$ away (Crook, 2001).

The Island Thunderstorm Experiment (ITEX) occurred over the Tiwi Islands in 1988 to facilitate improved understanding of tropical island convection. Golding (1993) numerically simulated Hector using the UK Met Office

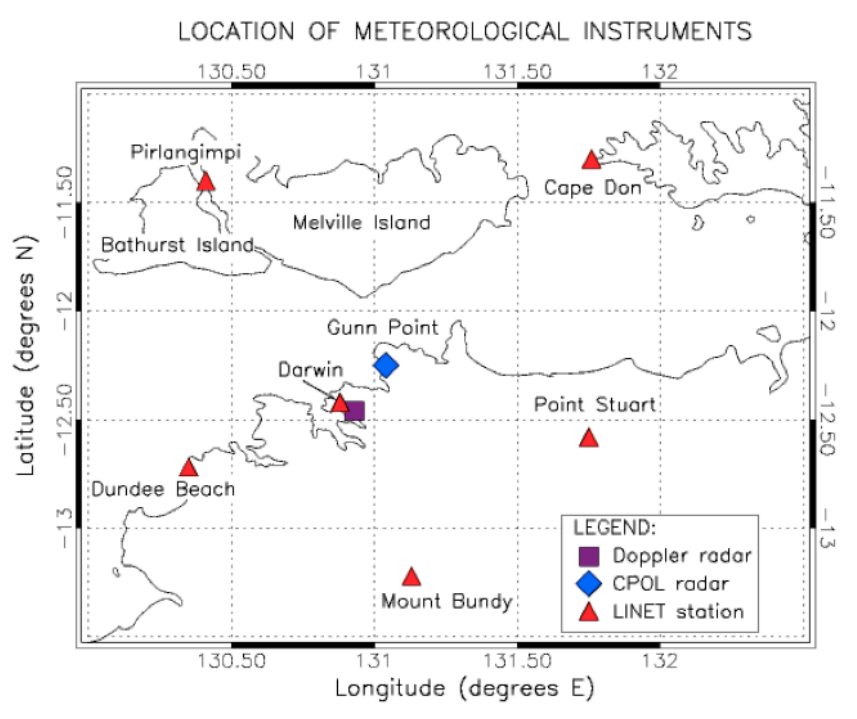

Fig. 1. Location of the two CAWCR radar and six LINET stations involved in the campaign.

mesoscale model and information from ITEX. While simulations showed some agreement with observations, the model placed convergence near the island's center when it was actually located near the south coast. Simulations demonstrated an island-scale confluence of sea breezes, cold pool interactions among breeze-forced storms, and storm development with little sensitivity to changes in cloud microphysics.

To further study deep island-based convection, the Maritime Continent Thunderstorm Experiment (MCTEX) was conducted in November-December 1995. Using observations from MCTEX, Carbone et al. (2000) created a conceptual model of Hector development. Carbone et al. (2000) suggest a flat, elliptical island of order $100-\mathrm{km}$ resolution can act as an heat source and create an optimal condition for the initiation, organization, and propagation of convection. The MCTEX simulations by Saito et al. (2001) found that the diurnal evolution of convective activity over the Tiwi Islands consisted of five stages, which capture the transition from horizontally to vertically forced convection. Shallow, nonprecipitating convective cells develop over the island interior, as well as within and ahead of the sea breeze fronts during the dry and condensation stages in the morning. By afternoon the convection is forced into the vertical as sea breeze fronts from opposite sides of the island move farther inland (precipitating stage), interacting near the leeward coast and causing a sudden increase in convective activity (merging stage).

The majority of Hector thunderstorms develop upon the interaction of the sea breeze and gust fronts from earlier convection. Simulations suggest the convective strength of a system increases as wind speed decreases and as wind direction turns toward the major axis of the island (Crook, 2001). If convection can free itself from the sea breeze maintenance mechanism, it can feed on the heated island boundary layer 

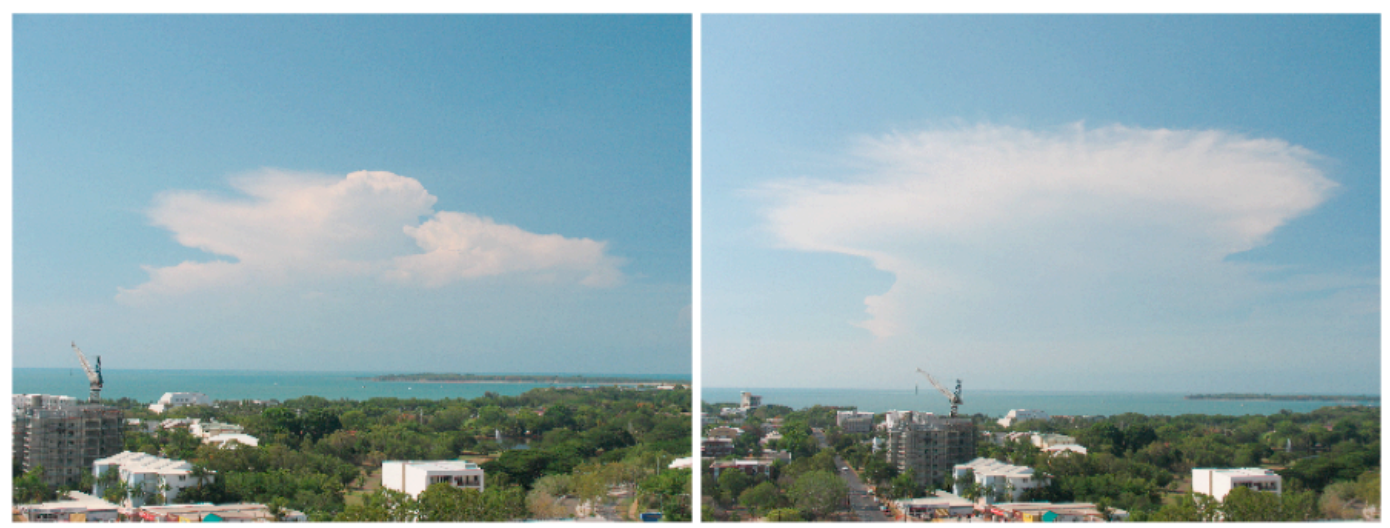

Fig. 2. Development of the Hector thunderstorm over the Tiwi Islands on 16 November 2005 during the SCOUT-O3/ACTIVE field campaign. From left to right, the photos indicate the stage of single-cell development at $\sim$ 16:19 LT and $\sim$ 17:09 LT, respectively.

when evaporatively produced cold pools become cooler than the nearby sea breeze. Thus, the convective strength, which was found to increase with increasing heat and moisture fluxes, was more sensitive to heat flux (Crook, 2001). But as daytime heating decreases, so does the convective activity (decay stage). The diurnal evolution indicated the horizontal island circulations, created in large part by the size and shape of the islands, and the vertical stability of the atmosphere both play important roles in the strength of the island convection.

Since deep island convection, like Hector, can penetrate the tropopause, numerical simulations are used to investigate the influence Hector thunderstorms have on the moisture in the upper troposphere and lower stratosphere. In the deep convective updrafts of overshooting tops, ice particles form in the rapidly cooling air and, if large enough, settle out and dehydrate the lower stratosphere (Chemel et al., 2009). If ice particles are not removed via sedimentation, their presence increases the potential for air to moisten by evaporation as particles slowly descend. Chemel et al. (2009) simulated the 30 November 2005 Hector storm observed during the SCOUT-O3/ACTIVE field campaign. The simulation indicated occasional overshooting tops affect the moistening or dehydration of the lower stratosphere via convective ice lofting. However, the impact of episodic vertical transport of short-lived boundary layer chemical species on the lower stratosphere was not investigated (Chemel et al., 2009).

\section{Observations}

This study focuses on a single-cell Hector storm observed on 16 November 2005 during the SCOUT-O3/ACTIVE (Brunner et al., 2009; Vaughan et al., 2008) field campaigns based in Darwin, Australia. Figure 2 shows a series of two photographs documenting the development of the Hector thunderstorm over the Tiwi Islands. This storm and its vicinity were sampled by the DLR Falcon, M55 Geophysica, Aus- tralia's Grob G520T Egrett, and the UK Natural Environment Research Council Dornier aircraft. Two radars owned and operated by the Centre for Australian Weather and Climate Research (CAWCR) were used on this day: the Darwin Berrimah Doppler radar and the C-Band Polarimetric (CPOL) radar based near Gunn Point. A lightning detection network (LINET) (Betz et al., 2004, 2007, 2008; Höller et al., 2009) of six stations was also established: Point Stuart, Cape Don, Pirlangimpi, Darwin, Dundee Beach, and Mount Bundy. Figure 1 provides the location of the radar and LINET stations. LINET detects individual strokes, which were then organized into flashes based on time of occurrence (within $1 \mathrm{~s}$ ) and location (within $10 \mathrm{~km}$ ). Flash data were obtained from 13:30 to 19:30 LT for the Hector storm of interest, although LINET collected data over the region for the entire day. Darwin rawinsondes were also available on this day.

Hector first appeared on radar at 14:28 LT over Apsley Strait between Melville and Bathurst Islands. Radar imagery shows the cell generally moves westward as it intensifies by $14: 58 \mathrm{LT}$, reaching a peak radar reflectivity of roughly $60 \mathrm{dBZ}$ by 16:00 LT. Satellite imagery indicates anvil development by 15:03 LT. By 16:38 LT, radar observations indicate the storm had begun to weaken and the anvil moved toward the south in response to the northerly upper tropospheric winds. Over the cell lifetime the anvil had an average area of $2365 \mathrm{~km}^{2}$ based on IR satellite images and the Droplet Measurement Technology (DMT) cloud, aerosol and precipitation spectrometer (CAPS) on board the Egrett. The cell is nearly dissipated by 18:28 LT based on radar.

The Geophysica approached the developing single-cell from the north, descending stepwise from $19 \mathrm{~km}$ to the anvil top, arriving as the detached anvil was already moving south. As the main convective activity was advected west, the Geophysica headed back northwest to sample overshoots of the cell, but ultimately returned to probing the environment above the main anvil by slowly descending into the cloud top. The two anvil transects made by the Geophysica occurred 
from roughly $11-17 \mathrm{~km}$ over the period 17:44-18:21 LT. The Falcon initially flew further north, sampling outflow from a large mesoscale system that had previously developed over Papua New Guinea. The Falcon returned to the area south of the Tiwi Islands where it flew east-west cross-sections below the anvil, characterizing its vertical structure by lidar. The Egrett aircraft, which most extensively sampled anvil cloud air above the Falcon from roughly $13.2-13.8 \mathrm{~km}$, began its first northeast-southwest oriented transect at 16:57 LT and completed its final anvil pass at 18:49LT. The Dornier characterized low-level inflow by flying large circles around the active cells. A cross calibration was performed on site in Darwin to ensure that differences in calibration standards did not cause variation in measurements amongst the aircraft.

\section{Numerical model}

The WRF version 2.2 model used a simple gas and aqueous chemistry scheme (WRF-AqChem) to simulate the Hector thunderstorm. WRF-AqChem is described in detail by Barth et al. (2007a) and the WRF meteorological model is described by Skamarock et al. (2005). This model uses nonhydrostatic compressible equations. The ice microphysics scheme (Lin et al., 1983) predicts the mass mixing ratios of cloud water, rain, cloud ice, snow, and hail. The model contains basic $\mathrm{O}_{3}-\mathrm{NO}_{\mathrm{x}}-\mathrm{CO}$ chemistry online with 16 chemical species in the gas phase and the five hydrometeor reservoirs. Diurnally-varying clear-sky photolysis rates as a function of altitude are derived from the Troposphere Ultraviolet and Visible (TUV) radiation code (Madronich and Flocke, 1999). Overhead cloudiness is not accounted for in the TUV code. Therefore, the photolysis rates may be underestimated in the upper portion of the cloud and overestimated below, affecting the partitioning of $\mathrm{NO}$ and $\mathrm{NO}_{2}$. However, this is not a concern because we evaluate the model $\mathrm{NO}_{\mathrm{x}}$ (sum of $\mathrm{NO}$ and $\mathrm{NO}_{2}$ ) against $\mathrm{NO}_{\mathrm{x}}$ observations. Other effects on chemistry (e.g., loss of $\mathrm{NO}_{2}$ to $\mathrm{HNO}_{3} ; \mathrm{O}_{3}$ production) will be minor over the short duration of the storm. Aqueous chemistry is computed for cloud water and rain. Partitioning of species between gas and liquid hydrometeors is assumed to be in Henry's Law equilibrium for most species, but diffusionlimited mass transfer partitions highly soluble or highly reactive species. Transfer of species also occurs during the transformation of gas to ice and between hydrometeor categories following the microphysics processes. $\mathrm{LNO}_{\mathrm{x}}$ production is implemented using the DeCaria et al. $(2000,2005)$ schemes.

For this simulation, the model is configured to a $300 \times 150 \times 25 \mathrm{~km}$ domain with 300 grid points in the eastwest direction and 150 grid points in the north-south direction at $1 \mathrm{~km}$ resolution and 60 grid points in the vertical direction with a variable resolution beginning at $40 \mathrm{~m}$ at the surface and stretching to $1840 \mathrm{~m}$ at the top of the domain, which is $25 \mathrm{~km}$. The Tiwi Islands are represented by a landmask in the model with sensible heating at the surface ap- plied following sunrise at $40 \%$ of solar flux (Crook, 2001). Lightning channel segments do not follow a uniform vertical distribution (MacGorman and Rust, 1998). Instead, the vertical distribution of CG and IC flashes follow single and bimodal Gaussian distributions, respectively, where the peaks indicate the maximum negative charge in the cloud (DeCaria et al., 2000). For this simulation, the lightning channels are set to maximize at $-15^{\circ} \mathrm{C}$ and $-60^{\circ} \mathrm{C}$, or $\sim 7.0 \mathrm{~km}$ and $\sim 12.7 \mathrm{~km}$, respectively. The channels are similar to midlatitude thunderstorms $\left(-15^{\circ} \mathrm{C}\right.$ and $\left.-45^{\circ} \mathrm{C}\right)$, except with a colder upper mode isotherm assumption due to the greater tropopause height in the tropics. The mean altitude of IC flashes for all types of observed storms over the 2005-2006 season was $12.2 \mathrm{~km}$ based on LINET observations. However, we would expect this altitude would be greater than $12.2 \mathrm{~km}$ in Hector storms, but we cannot be certain of the actual altitude for this particular storm. A more in depth analysis of the LINET data with regard to the vertical placement of IC flashes during our Hector storm is beyond the scope of this paper. NO production is tested at both 450 and 500 moles per CG and IC flash, which are approximately the mean values from the series of midlatitude and subtropical event simulations (Ott et al., 2010) described in Sect. 2.1. These values are used to determine whether NO production per flash in the Hector storm is similar to that in midlatitude or subtropical storms.

The model was initialized with a horizontallyhomogeneous environment using an atmospheric profile constructed from an early morning (08:30 LT) Darwin sounding (Fig. 3) and surface observations. Modifications were made to the temperature and moisture profiles using observations from a low-level Dornier flight and the boundary layer winds were adjusted to allow convection to form over the desired location. The sounding had a convective available potential energy (CAPE) value of $1360 \mathrm{~J} \mathrm{~kg}^{-1}$. The initial chemical profiles for $\mathrm{CO}, \mathrm{O}_{3}, \mathrm{NO}$, and $\mathrm{NO}_{2}$ were constructed from a composite of Dornier, Falcon, Geophysica, and Egrett aircraft data (Fig. 4). These data were restricted to times when the aircraft were located out-of-cloud and positioned primarily to the north of the developing cell. The vertical intervals of data used in the profile construction depended on the availability of data from each aircraft. For $\mathrm{CO}$ and $\mathrm{O}_{3}$, a combination of Dornier and Geophysica values were used from the surface to $3.5 \mathrm{~km}$. Between $3.5-5 \mathrm{~km}$, vertical layers were interpolated from the values at $3.5 \mathrm{~km}$ and $5 \mathrm{~km}$. Above $5 \mathrm{~km}$, Geophysica observations were used, except between $10-14 \mathrm{~km}$ where Egrett and Geophysica CO observations were averaged and smoothed. The CO profile shows spikes up to $125 \mathrm{ppbv}$ in the lowest $3 \mathrm{~km}$ of the boundary layer, which is most likely due to upwind biomass fires in northern Australia (Allen et al., 2008). When biomass burning did not occur under premonsoon conditions in the same field campaign, the average $\mathrm{CO}$ values for the lowest $3 \mathrm{~km}$ were roughly 85 ppbv (Allen et al., 2008). For $\mathrm{NO}$ and $\mathrm{NO}_{2}$ values, Falcon 


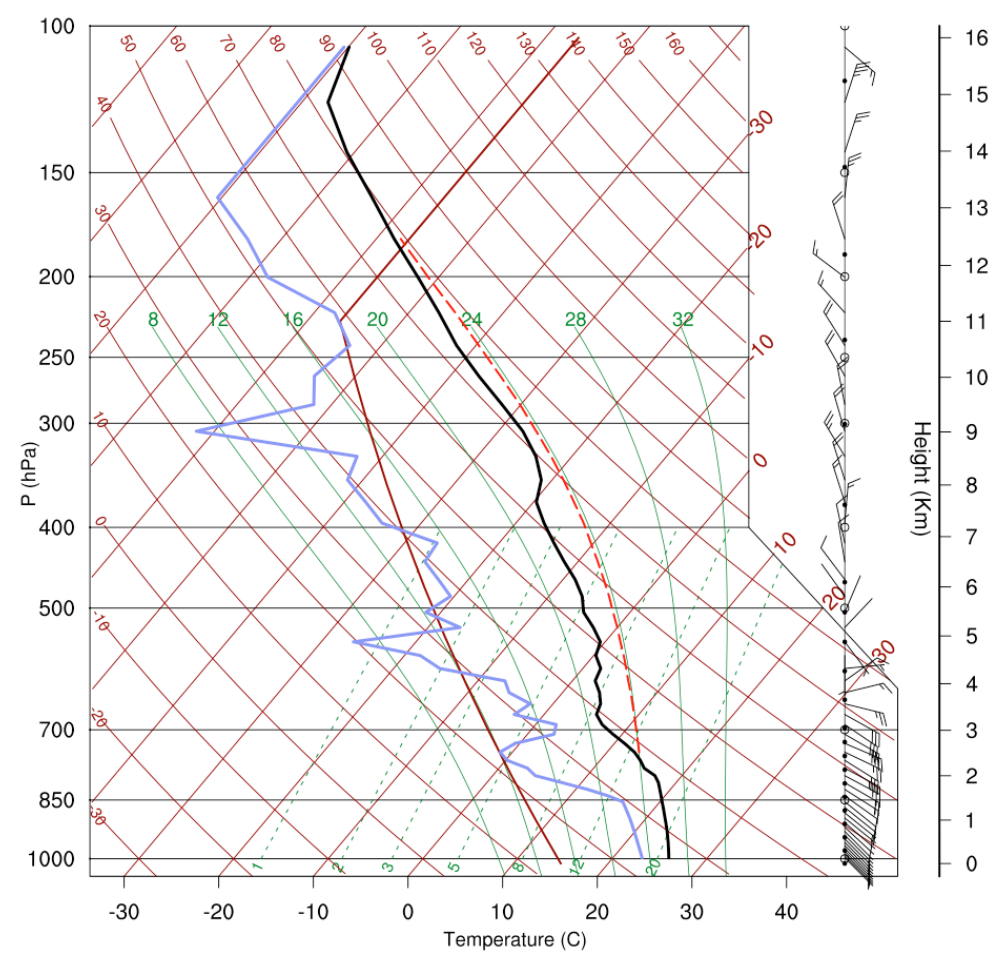

Fig. 3. Sounding used in the horizontally-homogeneous simulation initialization. Temperature and dew point are plotted as black and blue lines, respectively. Wind speed is reported in knots, where a full barb is equivalent to 10 knots.

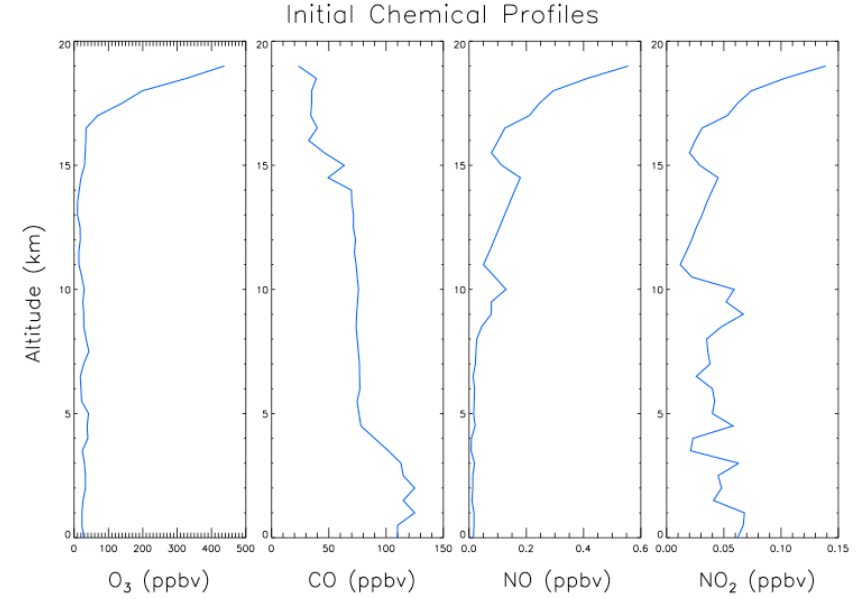

Fig. 4. Initial chemical profiles based on composite of Dornier, Falcon, Geophysica, and Egrett measurements.

averages were used below $9 \mathrm{~km}$ and Egrett averages were used above this altitude. The $\mathrm{NO}$ and $\mathrm{NO}_{2}$ profiles are enhanced in the upper troposphere due to upwind lightning.

The meteorological simulation was initiated at sunrise (07:15 LT). Chemistry and trace gas transport were started in the model at $4 \mathrm{~h} 30 \mathrm{~min}$ into the simulation (11:45 LT), which is just prior to the initial development of the main Hector cell of interest in the model. Convection intensified in the
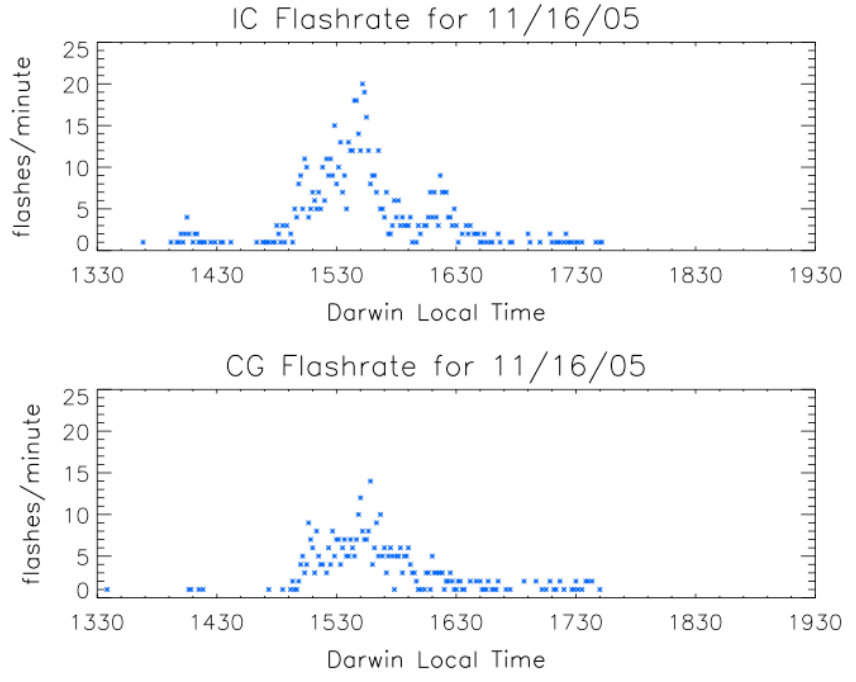

Fig. 5. Time series of IC and CG flashes per minute for 13:3019:30 LT for the selected Hector storm.

model simulation about $2 \mathrm{~h}$ earlier than in the observations (see Sect. 5). Therefore, the observed LINET flashes from the storm of interest, which occurred in real time between 14:4817:48 LT (Fig. 5), were read into the model at 10-s intervals beginning at $5 \mathrm{~h} 20 \mathrm{~min}$ into the simulation (12:35 LT). To keep the lightning flashes within the cell of interest, lightning 


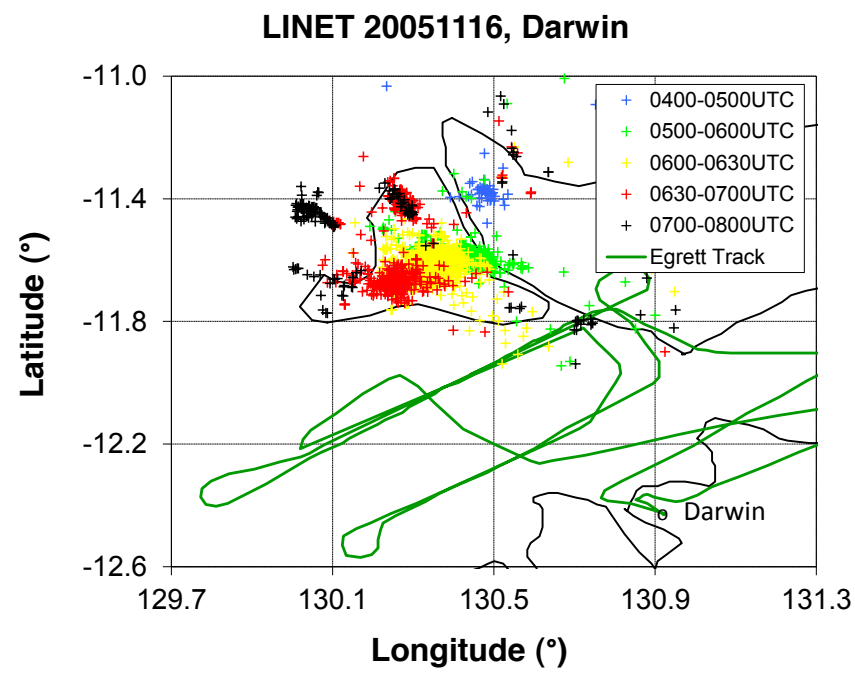

Fig. 6. Lightning strokes (CG and IC) observed by LINET on 16 November 2005 for the Hector thunderstorm that tracked across the Tiwi Islands between roughly 14:30-18:30 LT (05:00-09:00 UTC). The solid green line represents an approximation of the Egrett flight track through the anvil between 06:28-09:47 UTC (Isaac and Hacker, 2007).

flash rates read into the model were restricted using a spatial mask that was adjusted at 10-min intervals based on the movement of the cell within the model domain. There were 438 CG flashes with a mean absolute peak current value of $17.3 \mathrm{kA}$ and $683 \mathrm{IC}$ flashes with a mean absolute peak current value of $9.6 \mathrm{kA}$. The absolute values do not distinguish between negative and positive stroke signs. Observed flash rates peaked at approximately 15:40 LT, with a secondary peak at roughly 16:20 LT, which was followed by an extensive period of low flash rates (Fig. 5). The trend of observed flash rates generally followed the model simulated maximum vertical velocities and cloud top heights. Figure 6 illustrates the progression of LINET strokes from east-to-west with time.

\section{Results and discussion}

\subsection{Meteorology}

The WRF-AqChem idealized simulation reproduced a number of features of the observed storm (Table 2). Given the simulation begins at sunrise (07:15 LT), the simulated singlecell is assumed to begin at 11:55 LT, roughly $2.5 \mathrm{~h}$ earlier than the observed cell. The Geostationary Meteorological Satellite 5 (GMS-5) first saw the anvil at 15:03 LT, while the model indicates a two hour offset with initial anvil formation at $13 \mathrm{~km}$ occurring at 12:55 LT $(5 \mathrm{~h} 40 \mathrm{~min}$ simulation time). The modeled cell achieves its peak radar reflectivity of $\sim 65 \mathrm{dBZ}$ at $14: 15 \mathrm{LT}$. This is close to the observed peak radar reflectivity of $\sim 60 \mathrm{dBZ}$ at 16:00 LT, with a time offset
Table 2. Summary of the observed and simulated features in the 16 November 2005 Hector thunderstorm.

\begin{tabular}{lll}
\hline & Observations & Simulation \\
\hline Initial radar indication of cell at $2.5 \mathrm{~km}$ & $14: 28 \mathrm{LT}$ & $11: 55 \mathrm{LT}$ \\
\hline Initial anvil development at $13 \mathrm{~km}$ & $15: 03 \mathrm{LT}$ & $12: 55 \mathrm{LT}$ \\
\hline Peak radar reflectivity at $2.5 \mathrm{~km}$ & $\begin{array}{l}16: 00 \mathrm{LT} \\
(\sim 60 \mathrm{dBZ})\end{array}$ & $\begin{array}{l}14: 15 \mathrm{LT} \\
(\sim 65 \mathrm{dBZ})\end{array}$ \\
\hline Initial anvil dissipation at $13 \mathrm{~km}$ & $18: 03 \mathrm{LT}$ & $16: 15 \mathrm{LT}$ \\
\hline Complete cell dissipation at $2.5 \mathrm{~km}$ & $18: 28 \mathrm{LT}$ & $15: 55 \mathrm{LT}$ \\
\hline
\end{tabular}

of $1.75 \mathrm{~h}$. By 15:35 LT in the model, the anvil detached from the storm core and is blown toward the south.

The modeled anvil at $13 \mathrm{~km}$ dissipates by $16: 15 \mathrm{LT}(9 \mathrm{~h}$ simulation time) though satellite observations indicate the anvil dissipated by 18:03 LT. Thus, the anvil dissipation offset is $1.75 \mathrm{~h}$. The simulated cell dissipates in the model computed radar reflectivity at $2.5 \mathrm{~km}$ altitude by $15: 55 \mathrm{LT}$ whereas radar observations show the cell dissipating by 18:28 LT, indicating an offset of $2.5 \mathrm{~h}$. These time offsets between model and observations indicate that the simulation was on average $2 \mathrm{~h}$ earlier than observations. It may be when the low-level winds were modified to initiate convection in the correct location, that an earlier convergence of winds occurred. It is also possible that initializing the model with a sensible heat source of $40 \%$ of solar flux was too large and accelerated the onset of the storm, but as indicated above, the general features of Hector were still captured by the simulation.

The model computed radar reflectivity at $2.5 \mathrm{~km}$ altitude (Fig. 7 bottom) is compared with the observed radar from Gunn Point (Fig. 7 top) at an equivalent time in the storm life cycle. Both the model and the observations show the Hector cell over Bathurst Island and other scattered cells to the east. Vertical cross sections of model-computed radar reflectivity along an angle $130^{\circ}$ from the north through the core of the storm can be compared with observed vertical radar cross sections from Gunn Point (Fig. 8). Note that Fig. 8 shows vertical cross sections through the observed cell (top panel) and developing model storm (bottom panel) from the southeast to northwest (left to right). In the observations, the $20 \mathrm{dBZ}$ contour (cyan) extends to $16 \mathrm{~km}$. In the model simulation, the $20 \mathrm{dBZ}$ contour extends to roughly $16.5 \mathrm{~km}$. However, the observed $50 \mathrm{dBZ}$ contour (red/magenta interface) is roughly $7 \mathrm{~km}$ wide and reaches $4 \mathrm{~km}$ in altitude, while the model simulation indicates the $50 \mathrm{dBZ}$ contour extends to an altitude of $12.5 \mathrm{~km}$ and ranges in width from $\sim 10 \mathrm{~km}$ near the surface to $\sim 18 \mathrm{~km}$ around $5 \mathrm{~km}$ altitude. The simulated anvil slopes downward in Fig. 8 (bottom panel) away from the storm core, unlike the structure of the observed anvil. Differences in the observed and simulated $50 \mathrm{dBZ}$ contour and anvil structure in the radar reflectivity may be due to 

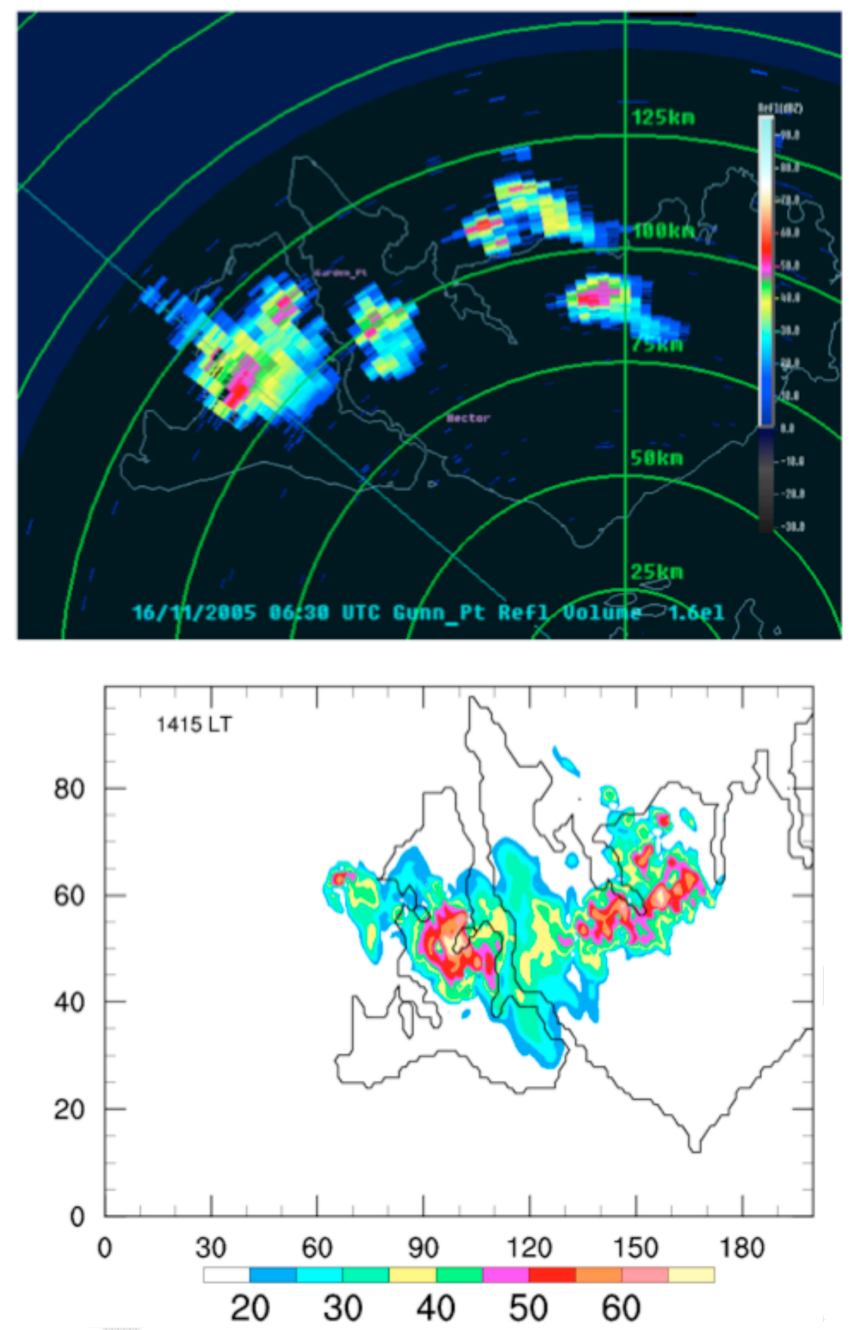

Fig. 7. Comparison of observed radar reflectivity at 16:00 LT (top, from Vaughan et al., 2008) to modeled $2.5 \mathrm{~km}$ reflectivity at 14:15 LT (bottom). Note the radar echo intensity (dBZ) in the observed radar reflectivity (top) is contoured at every $10 \mathrm{dBZ}$ with the $\mathrm{red} /$ magenta interface approximating $50 \mathrm{dBZ}$. The $\mathrm{x}$ - and $\mathrm{y}$-axes in the bottom figure show distance in $\mathrm{km}$.

how the ice mass concentrations are calculated in the WRFAqChem model, which uses a bulk microphysics scheme. Overestimates of reflectivity values in the middle to upper troposphere are a well-known bias common to many bulk microphysical schemes in simulations of tropical convective systems (Lang et al., 2011). Dahl et al. (2011a, b) indicate that environments where gust fronts and sea breezes collide, as over the Tiwi Islands, and high shear environments, as in the midlatitudes, can lead to an enhancement in graupel area within a simulated storm. The simulated total hydrometeors indicate the model cloud overshoots to $20 \mathrm{~km}$, which is typical of a Hector storm. The anvil hydrometeors may slope down and away from the simulated storm core due to a downward vertical motion at the storm's edge in response to
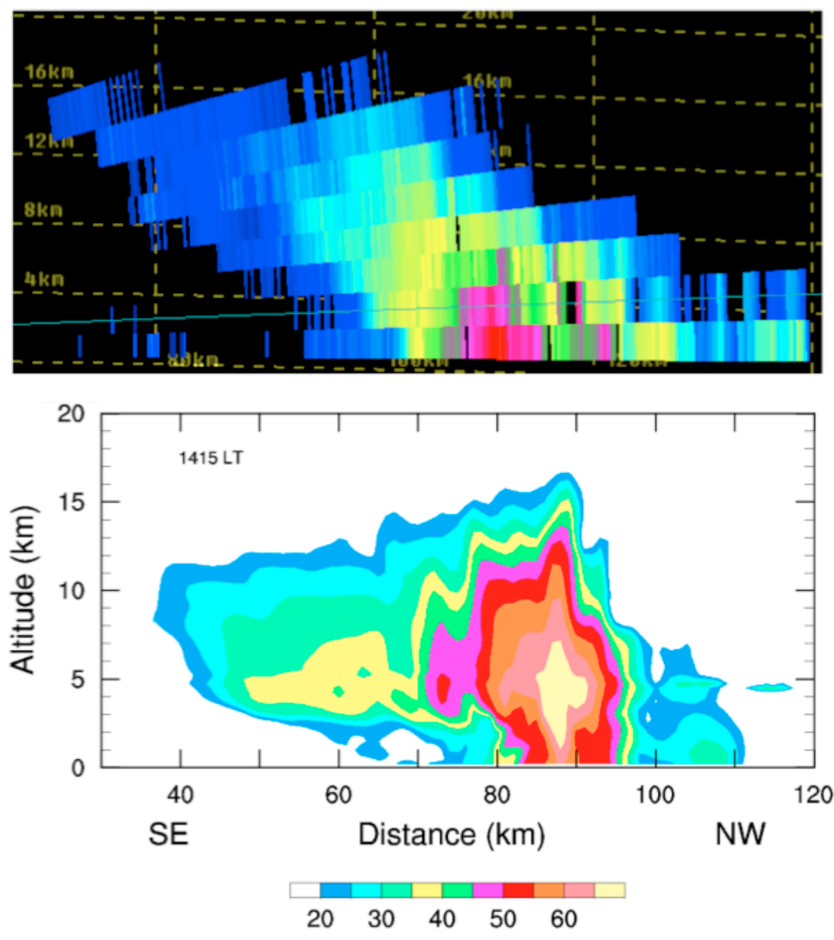

Fig. 8. Vertical cross section comparison of observed radar reflectivity at 16:00 LT (top, from Vaughan et al., 2008) to modeled reflectivity at 14:15 LT (bottom). The radar echo density (dBZ) is contoured in both vertical cross sections. Note that the observed radar reflectivity follows the same $\mathrm{dBZ}$ scaling as Fig. 7 (top).

the slight overestimation in upward transport within the core (see Sect. 5.2). It is also possible the sedimentation was too strong in the model, causing the downward slope. Chemel et al. (2009) showed the anvil in their simulated 30 November 2005 Hector storm also appeared to slope away from the core. The horizontal extent of the storm core and precipitation region in our Hector storm is about the same for both model results and observations $(\sim 40 \mathrm{~km})$, as is the extent of the anvil beyond the precipitation region.

Comparison of the anvil size from IR satellite images and Egrett in-cloud flight passes to modeled total hydrometeors at $13 \mathrm{~km}$ indicates anvil size in the simulation is comparable to both types of observations (Fig. 9). The average anvil extent over the cell lifetime is obtained from satellite observations and the DMT CAPS onboard the Egrett aircraft between 15:03-18:03 LT and 17:01-18:30 LT, respectively, and is estimated to be roughly $2400 \mathrm{~km}^{2}$. This estimate is slightly smaller than the model estimate of the average anvil extent at $13 \mathrm{~km}\left(2757 \mathrm{~km}^{2}\right)$ during the simulated anvil's lifetime (12:55-16:15 LT). Overall, the simulated storm structure compares favorably with observations, except for the extent of the $50 \mathrm{dBZ}$ contour. 


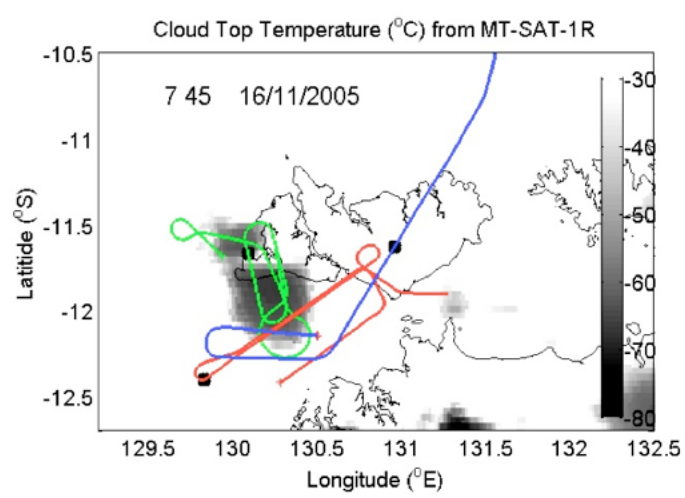

$13 \mathrm{~km}$ Total Hydrometeors $(\mathrm{g} / \mathrm{kg}) 1435 \mathrm{LT}$
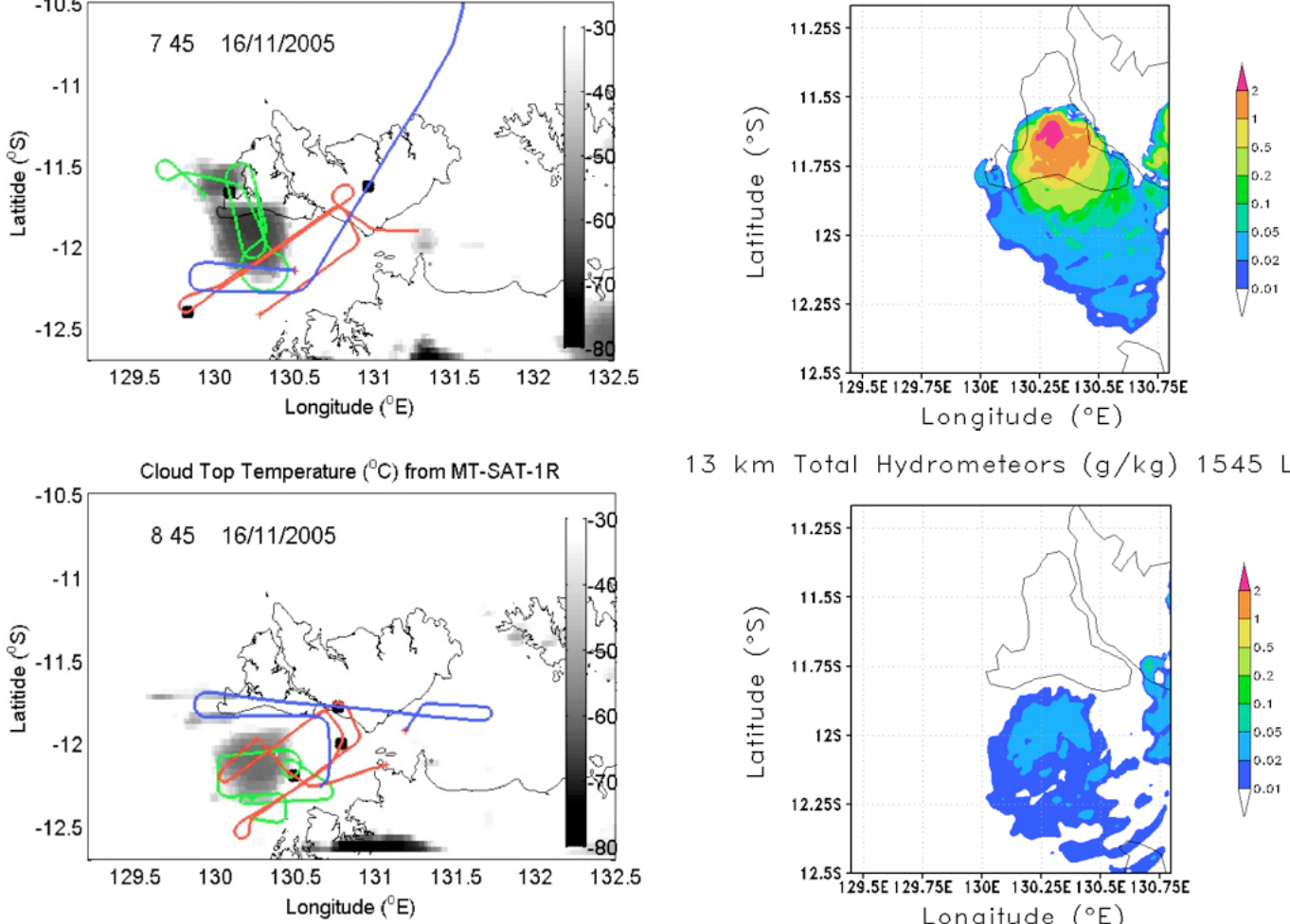

$13 \mathrm{~km}$ Total Hydrometeors $(\mathrm{g} / \mathrm{kg}) 1545 \mathrm{LT}$

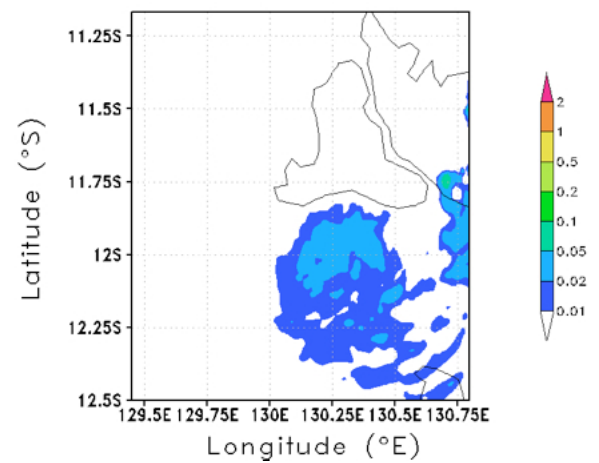

Fig. 9. Comparison of IR satellite anvil observations and aircraft flight tracks (left) with modeled total hydrometeors at $13 \mathrm{~km}$ (right). A summation of the area containing simulated total hydrometeors $\geq 0.01 \mathrm{~g} \mathrm{~kg}^{-1}$ provides an estimate of the anvil extent. Egrett flight track is in red, Geophysica in green, and Falcon in blue.

\subsection{Carbon monoxide}

Figure 10 shows a time series of vertical cross sections of $\mathrm{CO}$ mixing ratios from 12:55 LT ( $5 \mathrm{~h} 40 \mathrm{~min}$ simulation time) to 15:25 LT ( 8 h $10 \mathrm{~min}$ simulation time) through the simulated cell. Air that initially contained the maximum CO mixing ratios exceeding $100 \mathrm{ppbv}$ in the $0-4 \mathrm{~km}$ region is transported to over $16 \mathrm{~km}$ in the core updraft region and over $14 \mathrm{~km}$ in the anvil, indicating strong upward motion. In fact, modeled vertical velocities reached a maximum of $30 \mathrm{~m} \mathrm{~s}^{-1}$ in the core of the storm. Both the core and downwind anvil regions of the storm are largely composed of air that resided in the boundary layer prior to convection, while entrainment of environmental air with lower CO mixing ratios appears to be minimal.

Mixing ratios observed by the Egrett aircraft during the series of five anvil penetrations over the period 16:5718:49 LT were compared with the simulated tracer transport from 12:55-14:45 LT where anvil-in-cloud conditions were present (total hydrometeors $\geq 0.01 \mathrm{~g} \mathrm{~kg}^{-1}$ ). Data collected by the Egrett were averaged over 11-s intervals to yield a spatial scale equivalent to the model grid cell size. The mixing ratio statistics and specified initial conditions are shown in Tables 3 and 4 for lightning NO production scenarios of 450 and 500 moles flash $^{-1}$. Given that differences in the simulated $\mathrm{CO}$ mixing ratio statistics between the two scenarios are small, we will focus on the results from the lightning NO production scenario of 500 moles flash $^{-1}$, which are closer to the observations. The simulated $\mathrm{CO}$ mixing ratio statistics within the $0.71 \mathrm{~km}$ thick model layer centered at $13.4 \mathrm{~km}$ best match those based on the available Egrett observations between $13.2-13.8 \mathrm{~km}$ (Table 3), indicating vertical transport is generally well simulated by the model. Figure 11 shows the calculated probability density functions (PDFs) of observed and simulated $\mathrm{CO}$. The simulated convective transport increases $\mathrm{CO}$ values above the initial condition (70.1 ppbv) at many grid points, but the simulated and observed PDFs have significant differences. Egrett observations indicate a strong peak between $80-85$ ppbv with just over $25 \%$ of CO observations and a secondary peak between $95-100$ ppbv with $12 \%$ of the observations. The model distribution also shows two peaks, but they are slightly offset from the observations. Roughly $18 \%$ of the simulated $\mathrm{CO}$ mixing ratio values are within the primary peak between $70-75$ ppbv and a broader secondary peak covers the bins from 100-110 ppbv with roughly 9$10 \%$ of the simulated mixing ratios in each bin. The model simulation produces $\mathrm{CO}$ mixing ratios less than $65 \mathrm{ppbv}$ at this altitude, which are not observed, and most likely the 


\section{Modeled CO Mixing Ratios (ppbv)}

a) 12:55 LT

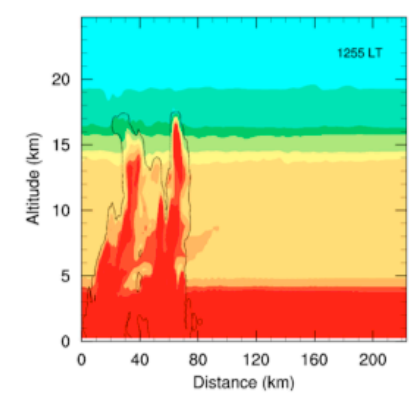

c) $14: 15 \mathrm{LT}$

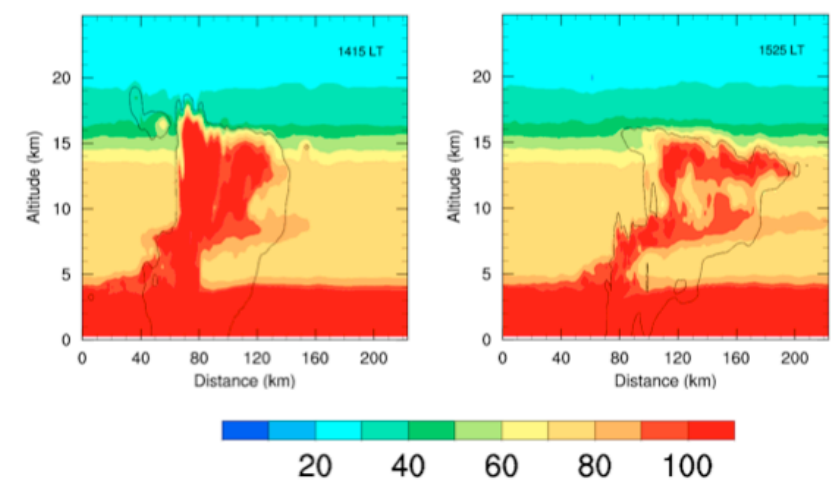

Fig. 10. Time series of vertical cross sections of CO mixing ratios from times (a) 12:55 LT, (b) 13:25 LT, (c) 14:15 LT, (d) 15:25 LT, oriented $130^{\circ}$ from north through the storm core. The thin black line indicates the $0.01 \mathrm{~g} \mathrm{~kg}^{-1}$ total condensate contour.

result of downward transport from higher altitudes in the model. In general, the model produces more extreme values, both large and small, than the observations. However, the total percentage of model anvil values greater than 80 ppbv was $57 \%$, closely matching the $62 \%$ found in the observations in the same layer. The simulated convection increases the mean value at $13.4 \mathrm{~km}$ to $85.8 \mathrm{ppbv}$ from the initial condition of 70.1 ppbv given 500 moles NO flash ${ }^{-1}$, slightly exceeding the observed value of $84.0 \mathrm{ppbv}$ by $1.8 \mathrm{ppbv}$ of simulated CO.

The raw tracer mixing ratios measured by the Geophysica were averaged over 5-s intervals between 17:44-18:21 LT and compared against the simulated tracer transport from 12:55-14:45 LT (Table 5). In the layers centered at 11.4$14.1 \mathrm{~km}$ the simulated $\mathrm{CO}$ mixing ratios overestimate the Geophysica observations by roughly $25-35 \%$ and reasonably replicate the values within $\pm 10 \%$ from $14.9-16.6 \mathrm{~km}$. The overestimation is partially due to the $\mathrm{CO}$ profile used to initialize the model, which was constructed using averages of the Egrett and Geophysica observations for each model layer between $10-14 \mathrm{~km}$. The resulting mixing ratios in this portion of the profile (70-75 ppbv) are slightly higher than those observed by the Geophysica in cloud-free air ( 65 ppbv). Correcting for this $10-15$ ppbv offset would reduce the model overestimates to $0-20 \%$. Cloud observations from the Geophysica indicate the aircraft passed in and out of the anvil (e.g., flew near cloud edge) and therefore, these data may not be representative of the anvil in general. The Geophysica CO observations show only minor effects (1-4 ppbv) of convective transport, but these data represent only a very small sample of the cloud air compared with that of the Egrett (see number of observations in Tables 3 and 5).

\subsection{Nitrogen oxides}

\subsection{1 $\mathrm{NO}_{\mathrm{x}}$ mixing ratios}

The CO analysis indicated small errors in simulated vertical transport, so it may not be necessarily correct to only compare observed and modeled trace gases from the same altitudes. In addition, there is uncertainty concerning the altitude where lightning channels maximize in the upper part of the cloud. Therefore, the $\mathrm{NO}_{\mathrm{x}}$ mixing ratio comparison with observations focuses on the model layers centered at $12.0 \mathrm{~km}$, $12.7 \mathrm{~km}$, and $13.4 \mathrm{~km}$.

For a simulation without lightning NO production, convection brings lower $\mathrm{NO}_{\mathrm{x}}$ mixing ratios upward to anvil levels (Fig. 12). At 14:45 LT in the simulation, at the end of the aircraft sampling period, the average $\mathrm{NO}_{\mathrm{x}}$ mixing ratio within the layers centered at $12.0 \mathrm{~km}$ and $12.7 \mathrm{~km}$ are $60 \mathrm{pptv}$ and 75 pptv, respectively, compared to $140 \mathrm{pptv}$ in the layer centered at $13.4 \mathrm{~km}$ at the start of the simulation. These are $57 \%$ and $46 \%$ decreases, respectively, largely due to convective transport.

The simulation with lightning tested two lightning NO

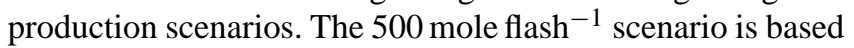
on the results of Ott et al. (2010) for midlatitude and subtropical thunderstorms, while the 450 mole flash $^{-1}$ scenario represents a $10 \%$ perturbation. Egrett $\mathrm{NO}_{\mathrm{x}}$ observations are based on sequential $\mathrm{NO}$ and $\mathrm{NO}_{\mathrm{x}}$ sampling. For the times when just NO was measured, a photostationary state calculation was used to estimate $\mathrm{NO}_{\mathrm{x}}$ using observed $\mathrm{NO}$ values, model $\mathrm{O}_{3}$ mixing ratios, temperature from the Darwin sounding, and $\mathrm{J}\left(\mathrm{NO}_{2}\right)$ from the TUV model. Table 4 indicates the model underestimated the mean anvil $\mathrm{NO}_{\mathrm{x}}$ when 450 moles NO is used, while 500 moles NO provides a closer estimate of the Egrett observations in the mean, especially for the model layer centered at $12.0 \mathrm{~km}$. These results show that mean $\mathrm{NO}_{\mathrm{x}}$ mixing ratios in the anvil are approximately linearly related to the $\mathrm{LNO}_{\mathrm{x}}$ production rate per flash $(\sim 10 \%$ reduction in mixing ratios for $10 \%$ reduction in $\mathrm{LNO}_{\mathrm{x}}$ production per flash). Given these results, the remainder of the $\mathrm{NO}_{\mathrm{x}}$ analysis focuses on the lightning NO production scenario which uses 500 moles NO flash $^{-1}$. However, the mean anvil mixing ratio at $13.4 \mathrm{~km}$ is $705 \mathrm{pptv}$, which is less than the observed value (Table 5). Therefore, using the demonstrated linearity we cannot rule out a mean $\mathrm{LNO}_{\mathrm{x}}$ production of 600 moles flash $^{-1}$. For a simulation with lightning NO production (using the DeCaria et al., 2005 scheme with 
Table 3. Egrett observed and simulated CO mixing ratio statistics for the layer centered at $13.4 \mathrm{~km}$. Simulated values are based on a lightning NO production scenario of 450 and 500 moles flash $^{-1}$. The layer centered at $13.4 \mathrm{~km}$ contained $35111-\mathrm{s}$ Egrett observations and 1268 simulated values.

\begin{tabular}{lcccc}
\hline & Initial Condition CO (ppbv) & Observed Anvil CO (ppb) & \multicolumn{2}{c}{ Simulated Anvil CO (ppbv) } \\
\cline { 3 - 5 } & & & 450 moles NO flash $^{-1}$ & 500 moles NO flash $^{-1}$ \\
\hline Mean & 70.1 & 84.0 & 86.9 & 85.8 \\
Maximum & - & 114.5 & 117.4 & 117.4 \\
Standard Deviation & - & 9.9 & 15.3 & 14.8 \\
\hline
\end{tabular}

Table 4. Statistics for the Egrett observed $\mathrm{NO}_{\mathrm{x}}$ mixing ratios for the layer centered at $13.4 \mathrm{~km}$ compared with the simulated $\mathrm{NO}_{\mathrm{x}}$ mixing ratios for the layers centered at $12.0 \mathrm{~km}$ and $12.7 \mathrm{~km}$. Simulated values are based on a lightning NO production scenario of 450 and 500 moles flash $^{-1}$. The layer centered at $13.4 \mathrm{~km}$ contained 33811 -s Egrett observations and the layers centered at $12.0 \mathrm{~km}(12.7 \mathrm{~km}) \mathrm{con}$ tained 2236 (1782) simulated values.

\begin{tabular}{|c|c|c|c|c|}
\hline \multicolumn{5}{|c|}{450 moles NO Flash ${ }^{-1}$} \\
\hline & \multirow{2}{*}{ Initial Condition $\mathrm{NO}_{\mathrm{x}}$ (pptv) } & \multirow{2}{*}{ Observed Anvil $\mathrm{NO}_{\mathrm{x}}$ (pptv) } & \multicolumn{2}{|c|}{ Simulated Anvil $\mathrm{NO}_{\mathrm{x}}$ (pptv) } \\
\hline & & & $12.0 \mathrm{~km}$ & $12.7 \mathrm{~km}$ \\
\hline Mean & 140 & 845 & 758 & 739 \\
\hline Maximum & - & 5139 & 2678 & 2606 \\
\hline Standard Deviation & - & 1140 & 692 & 602 \\
\hline \multicolumn{5}{|c|}{500 moles NO Flash ${ }^{-1}$} \\
\hline & \multirow{2}{*}{ Initial Condition $\mathrm{NO}_{\mathrm{x}}$ (pptv) } & \multirow{2}{*}{ Observed Anvil $\mathrm{NO}_{\mathrm{x}}$ (pptv) } & \multicolumn{2}{|c|}{ Simulated Anvil $\mathrm{NO}_{\mathrm{x}}(\mathrm{pptv})$} \\
\hline & & & $12.0 \mathrm{~km}$ & $12.7 \mathrm{~km}$ \\
\hline Mean & 140 & 845 & 834 & 811 \\
\hline Maximum & - & 5139 & 2970 & 2889 \\
\hline Standard Deviation & - & 1140 & 769 & 670 \\
\hline
\end{tabular}

parameters as specified in Sect. 4), $\mathrm{NO}_{\mathrm{x}}$ mixing ratios exceed $3 \mathrm{ppbv}$ in the storm core (Fig. 13). Downwind of the storm core, anvil $\mathrm{NO}_{\mathrm{x}}$ values slightly exceed 3 ppbv for roughly a $25 \mathrm{~km}$ distance (Fig. 14). The finding of $\mathrm{NO}_{\mathrm{x}}$ production of 500 moles flash $^{-1}$ or larger is consistent with that estimated for CG flashes ( 523 moles flash $^{-1}$ ) based on the observed mean peak current using the relationship given by Price et al. (1997). If the Price et al. (1997) relationship is assumed to also hold for IC flashes, one would obtain an estimate of 291 moles flash $^{-1}$. The model results clearly indicate an NO production per IC flash larger than this value is needed to match observed anvil $\mathrm{NO}_{\mathrm{x}}$ observations.

The PDFs in Fig. 15 compare the distribution of model $\mathrm{NO}_{\mathrm{x}}$ centered at $12.0 \mathrm{~km}$ and $12.7 \mathrm{~km}$ with the Egrett observed $\mathrm{NO}_{\mathrm{x}}$. For either layer, the model $\mathrm{NO}_{\mathrm{x}} \mathrm{PDF}$ did not match the shape of the observations well. Though the mean anvil-level $\mathrm{NO}_{\mathrm{x}}$ in both model layers adequately reflects the mean of the Egrett anvil-level observations, a substantial fraction of observations between 200-400 pptv and above 2400 pptv are missing from the simulated $\mathrm{NO}_{\mathrm{x}}$. The Egrett observations $>2400$ pptv may be from relatively fresh lightning flashes encountered by the aircraft and not captured with the DeCaria et al. (2005) scheme, which places $\mathrm{NO}_{\mathrm{x}}$ into the model cloud in bulk fashion. In this scheme the NO production is injected within the $20 \mathrm{dBZ}$ contour of the storm and according to prescribed Gaussian vertical distributions (e.g., not along specific channels). As a result, the model standard deviation remains smaller than observed by $43 \%$ and the upper end of the distribution is slightly underestimated. A broad secondary peak in model-simulated $\mathrm{NO}_{\mathrm{x}}$ occurs in the bins between 1000-2400 pptv, overestimating the Egrett observations. Therefore, the magnitude of the $\mathrm{NO}_{\mathrm{x}}$ peaks seen in the aircraft data are not reflected in the model results, which indicates that individual model grid cells contain smaller $\mathrm{NO}_{\mathrm{x}}$ peaks than the observations. Future improvements to this simulation should include a $\mathrm{LNO}_{\mathrm{x}}$ parameterization (Ott et al., 2007; Barthe and Barth, 2008) that would inject $\mathrm{NO}_{\mathrm{x}}$ along specific channels of individual flashes.

The simulated $\mathrm{NO}_{\mathrm{x}}$ mixing ratios underestimate the Geophysica measurements within the layers centered at 13.4$14.9 \mathrm{~km}$, and overestimate the observations at the other layers (Table 5). The underestimation by the model may be due to the Geophysica sampling a number of fresh lightning flashes whereas the model values are more representative 
Table 5. Statistics for the Geophysica observed and simulated tracer mixing ratios for multiple layers centered at $11.4-16.6 \mathrm{~km}$. Simulated values are based on a lightning NO production scenario of 500 moles flash $^{-1}$.

\begin{tabular}{|c|c|c|c|c|c|c|c|}
\hline \multirow{2}{*}{ Altitude $(\mathrm{km})$} & \multirow{2}{*}{ \# Obs } & \multicolumn{2}{|c|}{ Mean CO (ppbv) } & \multicolumn{2}{|c|}{ Maximum CO (ppbv) } & \multicolumn{2}{|c|}{ CO Standard Deviation (ppbv) } \\
\hline & & Observed & Simulated & Observed & Simulated & Observed & Simulated \\
\hline 11.4 & 1 & 67.6 & 90.5 & 67.6 & 117.0 & - & 10.8 \\
\hline 12.0 & 11 & 66.1 & 93.8 & 67.4 & 124.5 & 0.6 & 10.4 \\
\hline 12.7 & 20 & 68.6 & 91.0 & 71.4 & 123.3 & 1.0 & 11.8 \\
\hline 13.4 & 33 & 67.9 & 85.8 & 74.5 & 117.4 & 4.0 & 15.3 \\
\hline 14.1 & 43 & 65.1 & 80.8 & 68.2 & 118.0 & 1.9 & 18.1 \\
\hline 14.9 & 42 & 66.0 & 75.3 & 72.2 & 122.9 & 4.7 & 20.7 \\
\hline 15.7 & 66 & 70.3 & 65.8 & 75.5 & 126.4 & 4.9 & 19.1 \\
\hline 16.6 & 32 & 59.3 & 63.0 & 63.9 & 124.6 & 2.7 & 15.2 \\
\hline \multirow{2}{*}{ Altitude $(\mathrm{km})$} & \multirow{2}{*}{ \# Obs } & \multicolumn{2}{|c|}{ Mean $\mathrm{NO}_{\mathrm{x}}(\mathrm{pptv})$} & \multicolumn{2}{|c|}{ Maximum $\mathrm{NO}_{\mathrm{x}}$ (pptv) } & \multicolumn{2}{|c|}{$\mathrm{NO}_{\mathrm{x}}$ Standard Deviation (pptv) } \\
\hline & & Observed & Simulated & Observed & Simulated & Observed & Simulated \\
\hline 11.4 & 0 & - & 639 & - & 2840 & - & 700 \\
\hline 12.0 & 4 & 10 & 834 & 13 & 2970 & 4 & 769 \\
\hline 12.7 & 20 & 476 & 811 & 922 & 2889 & 258 & 670 \\
\hline 13.4 & 16 & 984 & 705 & 3028 & 2745 & 967 & 617 \\
\hline 14.1 & 30 & 2826 & 587 & 3363 & 2540 & 621 & 604 \\
\hline 14.9 & 38 & 597 & 475 & 1654 & 2248 & 548 & 534 \\
\hline 15.7 & 52 & 162 & 364 & 243 & 2036 & 31 & 408 \\
\hline 16.6 & 32 & 94 & 432 & 118 & 1760 & 7 & 283 \\
\hline
\end{tabular}

of lightning emissions that are more dispersed, as indicated by the smaller standard deviations in the simulation. Strong vertical motions within the simulated storm likely bring enhanced $\mathrm{NO}_{\mathrm{x}}$ mixing ratios from injected lightning at midcloud and from the stratosphere, leading to an overestimation of observed $\mathrm{NO}_{\mathrm{x}}$. Uncertainty in initial conditions may also cause an overestimation in $\mathrm{NO}_{\mathrm{x}}$, as the Geophysica measured smaller values just inside the edge of the anvil during the storm in the lower and upper layers compared with the mean Egrett out-of-cloud values used in the initial conditions profile.

\subsection{2 $\mathrm{NO}_{2}$ column amounts}

$\mathrm{LNO}_{2}$ satellite observations have been described by Boersma et al. (2005), Beirle et al. (2009, 2010), and Bucsela et al. (2010). The importance of investigating $\mathrm{LNO}_{2}$ signals with satellite observations is to identify regional differences in thunderstorm contribution to $\mathrm{NO}_{2}$ (Beirle et al., 2010). Here the $\mathrm{NO}_{2}$ column analysis provides the $\mathrm{NO}_{2}$ satellite retrieval community with potential outflow expectations for a highly electrified, high $\mathrm{NO}_{\mathrm{x}}$ producing storm. Figure 16 shows the maximum simulated $\mathrm{NO}_{2}$ tropospheric column values that potentially could be observed for the Hector storm by satellite from the tropopause to $400 \mathrm{mb}$ and $600 \mathrm{mb}$ at 14:45 LT. These are pressures within a thunderstorm cloud to which $\mathrm{NO}_{2}$ is thought to be observable from space. Actual visibility of $\mathrm{LNO}_{2}$ from satellite may differ from these values due to the particular radiative transfer characteris-

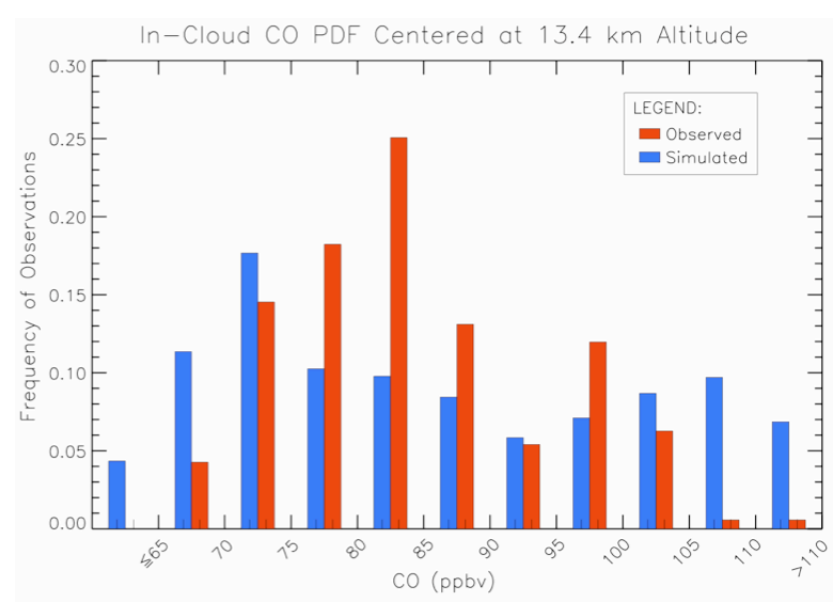

Fig. 11. PDF of observed Egrett (red) and simulated (blue) CO mixing ratios in the model layers centered at $13.4 \mathrm{~km}$ given 500 moles NO flash $^{-1}$.

tics of the cloud. The largest mean partial $\mathrm{NO}_{2}$ column values $\left(\geq 60 \times 10^{14}\right.$ molecules $\left.\mathrm{cm}^{-2}\right)$ are located along and just south of Apsley Strait. Low-level radar reflectivity indicate Hector is on the western coast of Bathurst Island prior to 14:45 LT (Fig. 7). With northerly upper level winds (Fig. 3) and a westward motion of the storm track across the Tiwi Islands, $\mathrm{NO}_{2}$ is transported away from the storm core and along the anvil, explaining the placement of the large mean $\mathrm{NO}_{2}$ column values. However, the Ozone Monitoring 


\section{Modeled $\mathrm{NO}_{x}$ Mixing Ratios (ppbv) without Lightning}

a) 13:05 LT

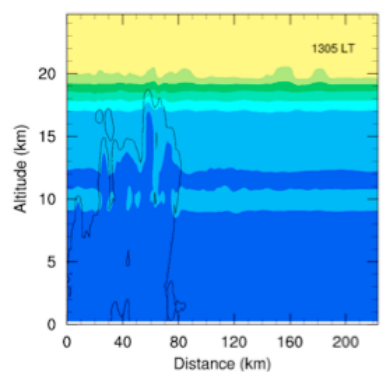

b) $13: 25 \mathrm{LT}$

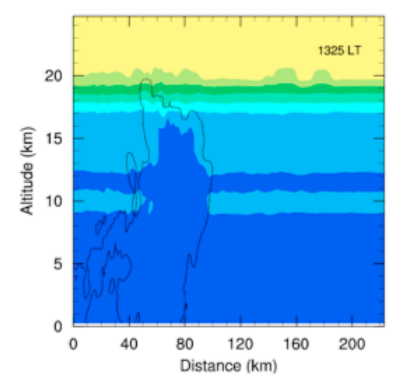

c) 14:05 LT

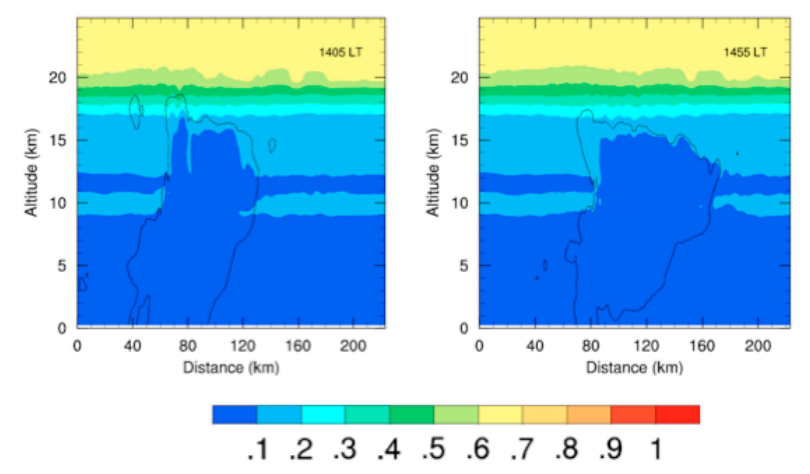

Fig. 12. Time series of vertical cross sections of $\mathrm{NO}_{\mathrm{x}}$ mixing ratios for simulations without lightning NO production at (a) 13:05 LT, (b) 13:25 LT, (c) 14:05 LT, and (d) 14:55 LT, oriented $130^{\circ}$ from north through the storm core. The thin black line indicates the $0.01 \mathrm{~g} \mathrm{~kg}^{-1}$ total condensate contour.

Instrument (OMI) on NASA's Aura satellite passed over at $\sim$ 13:30 LT, which was too early to observe the $\mathrm{LNO}_{\mathrm{x}}$ from Hector. $\mathrm{A} \mathrm{LNO}_{2}$ signal was not found during the OMI over pass at $\sim 13: 30 \mathrm{LT}$ or $\sim 15: 00 \mathrm{LT}$. There is still much uncertainty in observing $\mathrm{LNO}_{2}$ from space, as the $\mathrm{NO}_{2}$ signal is detected by satellite for some thunderstorms and not others (Beirle et al., 2010).

Tropospheric column $\mathrm{NO}_{2}$ from the simulated Hector storm is compared with columns computed from midlatitude storm simulations (Ott et al., 2010) and with OMI observations for tropical marine thunderstorm events from NASA's Tropical Composition, Cloud and Climate Coupling $\left(\mathrm{TC}^{4}\right)$ experiment near Costa Rica and Panama (Bucsela et al., 2010). Ott et al. (2010) indicated partial $\mathrm{NO}_{2}$ column amounts peaked over similar regions (relative to the storm core) in the simulated storm anvils during CRYSTALFACE (Cirrus Regional Study of Tropical Anvils and Cirrus Layers - Florida Area Cirrus Experiment), STERAO, and EULINOX. In the Hector storm cloud the mean partial $\mathrm{NO}_{2}$ column amounts from $400 \mathrm{mb}$ to the tropopause (Fig. 16 left panel) are the same order of magnitude as the storms from CRYSTAL-FACE, STERAO, and EULINOX. The maximum partial $\mathrm{NO}_{2}$ column amounts from

\section{Modeled $\mathrm{NO}_{\mathrm{x}}$ Mixing Ratios (ppbv) with Lightning}

a) 13:05 LT

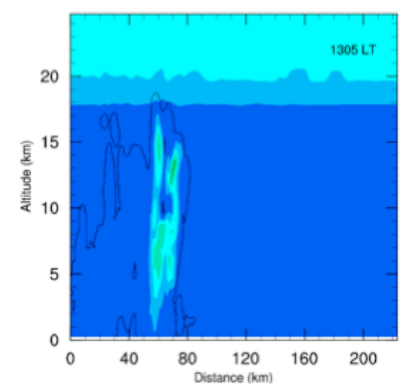

c) 14:05 LT

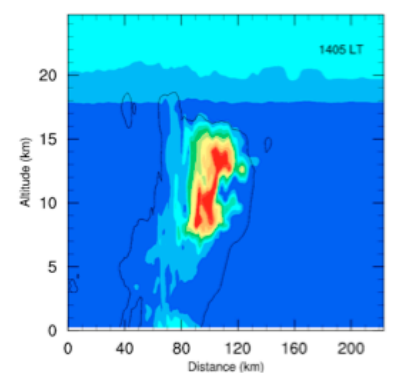

b) 13:25 LT

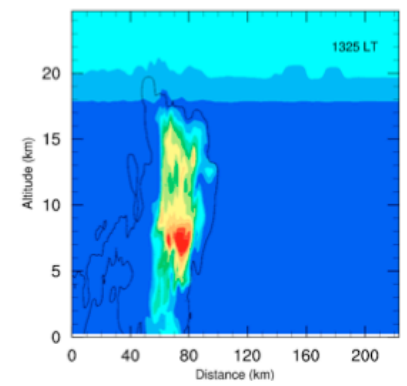

d) 14:55 LT

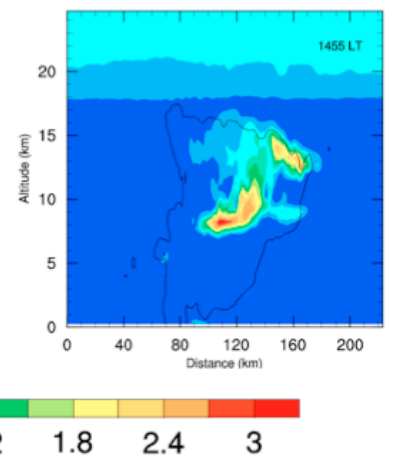

Fig. 13. Time series of vertical cross sections of $\mathrm{NO}_{\mathrm{x}}$ mixing ratios for simulations with lightning NO production of 500 moles flash $^{-1}$ at (a) 13:05 LT, (b) 13:25 LT, (c) 14:05 LT, and (d) 14:55 LT, oriented $130^{\circ}$ from north through the storm core. The thin black line indicates the $0.01 \mathrm{~g} \mathrm{~kg}^{-1}$ total condensate contour.

the tropopause to $400 \mathrm{mb}\left(\sim 84 \times 10^{14}\right.$ molecules $\left.\mathrm{cm}^{-2}\right)$ and $600 \mathrm{mb}\left(\sim 103 \times 10^{14}\right.$ molecules $\left.\mathrm{cm}^{-2}\right)$, following the end of lightning flash injections into the model, indicate the incloud column amounts fall within the range of peak values for the subtropical and midlatitude storms analyzed by Ott et al. (2010), but are larger than those found in the $\mathrm{TC}^{4}$ storms $\left(\sim 45 \times 10^{14}\right.$ molecules $\left.\mathrm{cm}^{-2}\right)$.

\subsection{3 $\quad \mathrm{NO}_{\mathrm{x}}$ vertical profiles}

Vertical profiles of the average in-cloud simulated $\mathrm{NO}_{\mathrm{x}}$ mixing ratios with and without lightning were compared at 13:55 LT (Fig. 17). In the lightning simulation two large $\mathrm{NO}_{\mathrm{x}}$ peaks $(\sim 0.95-1.05 \mathrm{ppbv})$ occur around $8.5 \mathrm{~km}$ and $13.5 \mathrm{~km}$. The peak at $13.5 \mathrm{~km}$ is $\sim 0.8 \mathrm{~km}$ higher than the prescribed upper mode $\left(-60^{\circ}\right.$ isotherm) height in the $\mathrm{LNO}_{\mathrm{x}}$ vertical distribution, while the peak at $8.5 \mathrm{~km}$ is roughly $1.5 \mathrm{~km}$ higher than the prescribed lower mode $\left(-15^{\circ}\right.$ isotherm). Secondary peaks are also noted near the surface and around $6 \mathrm{~km}$ with $\sim 0.5 \mathrm{ppbv}$ and $\sim 0.75 \mathrm{ppbv} \mathrm{NO}_{\mathrm{x}}$, respectively. Without lightning, the profile is similar to the initial $\mathrm{NO}_{\mathrm{x}}$ chemical profile in Fig. 4 in the lower troposphere, but upward transport caused upper tropospheric values to be lower than the 


\section{Modeled $\mathrm{NO}_{\mathrm{x}}$ Mixing Ratios (ppbv)}

a) 13:05 LT

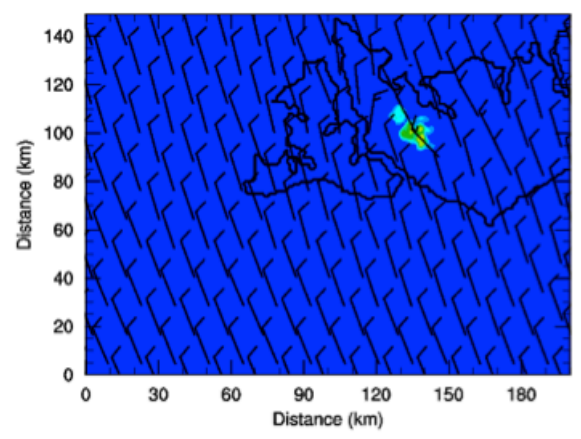

c) $14: 05$ LT

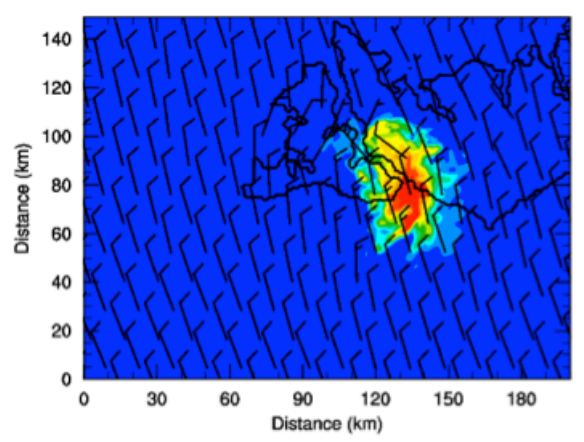

b) $13: 25 \mathrm{LT}$

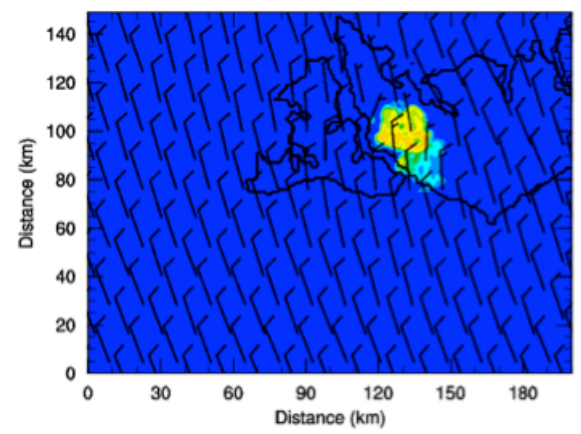

d) $14: 55 \mathrm{LT}$

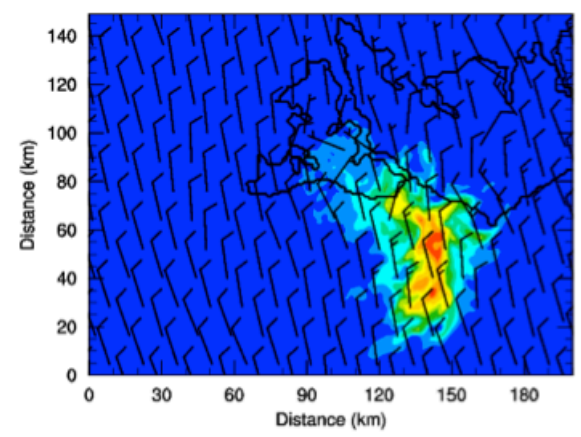

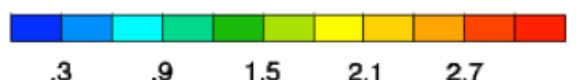

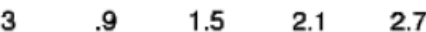

Fig. 14. Time series of $\mathrm{NO}_{\mathrm{x}}$ mixing ratios at $13 \mathrm{~km}$ for simulations with lightning NO production of 500 moles flash ${ }^{-1}$ at (a) 13:05 LT, (b) 13:25 LT, (c) 14:05 LT, and (d) 14:55 LT. Arrows indicate wind vectors at $13 \mathrm{~km}$. Wind speed is reported in $\mathrm{m} \mathrm{s}^{-1}$, where a full barb is equivalent to $10 \mathrm{~m} \mathrm{~s}^{-1}$.

initial conditions. With lightning, the peaks in $\mathrm{NO}_{\mathrm{x}}$ mixing ratios are likely due to a combination of the lightning injection location and vertical transport within the cloud.

The cloud-resolved model analysis of Pickering et al. (1998) produced average profiles of $\mathrm{LNO}_{\mathrm{x}}$ mass for midlatitude continental, tropical continental, and tropical marine regimes all showing peaks in mass near the surface and in the upper troposphere. These $\mathrm{C}$-shaped vertical distributions of $\mathrm{LNO}_{\mathrm{x}}$ mass were adopted by many global chemical transport models (CTMs). Ott et al. (2010) produced an updated set of $\mathrm{LNO}_{\mathrm{x}}$ mass profiles for midlatitude and subtropical storms using a more realistic scheme of vertical placement of $\mathrm{LNO}_{\mathrm{x}}$ in the cloud-resolved model. For additional comparison against tropical convection, Fig. 18 shows the percentage of $\mathrm{N}$ mass per kilometer due to $\mathrm{LNO}_{\mathrm{x}}$ for this idealized Hector simulation following the end of model convection at 15:35 LT. Approximately $85 \%$ of the simulated $\mathrm{LNO}_{\mathrm{x}}$ is located above $7 \mathrm{~km}$. The maximum peak in total lightning $\mathrm{N}$ mass $(\sim 20 \%)$ is located within the layer centered at $\sim 7.5 \mathrm{~km}$ and roughly corresponds to the lower mode of the vertical distribution of the $\mathrm{LNO}_{\mathrm{x}}$ source. A second peak ( $\sim 9.5 \%)$ around $\sim 13.5 \mathrm{~km}$ is $\sim 0.8 \mathrm{~km}$ higher than the upper isotherm $\left(-60^{\circ} \mathrm{C}\right)$. The vertical distribution did not resemble the tropical continental profile hypothesized by Ott et al. (2010), which had a dominant peak at $11-14 \mathrm{~km}$. Instead, the vertical profile of the percentage of $\mathrm{LNO}_{\mathrm{x}}$ mass per kilometer for our Hector storm resembles the average midlatitude continental profile from Ott et al. (2010), except shifted $\sim 3 \mathrm{~km}$ higher in altitude. It is possible the directional shear within this storm, discussed below, played a key role in the profile shape.

Based on these results, a lightning NO production scenario of 500 moles flash $^{-1}$ in this Hector storm is roughly equivalent to the mean of the midlatitude and subtropical events previously studied with a similar approach. The wind speed difference, on the other hand, in the $850-200 \mathrm{hPa}$ layer is only $5 \mathrm{~m} \mathrm{~s}^{-1}$ in the Hector system compared to the $20 \mathrm{~m} \mathrm{~s}^{-1}$ and $30 \mathrm{~m} \mathrm{~s}^{-1}$ variation in wind speed between similar pressure levels for the STERAO and EULINOX midlatitude cases. Wind direction variation in the Hector storm, however, 

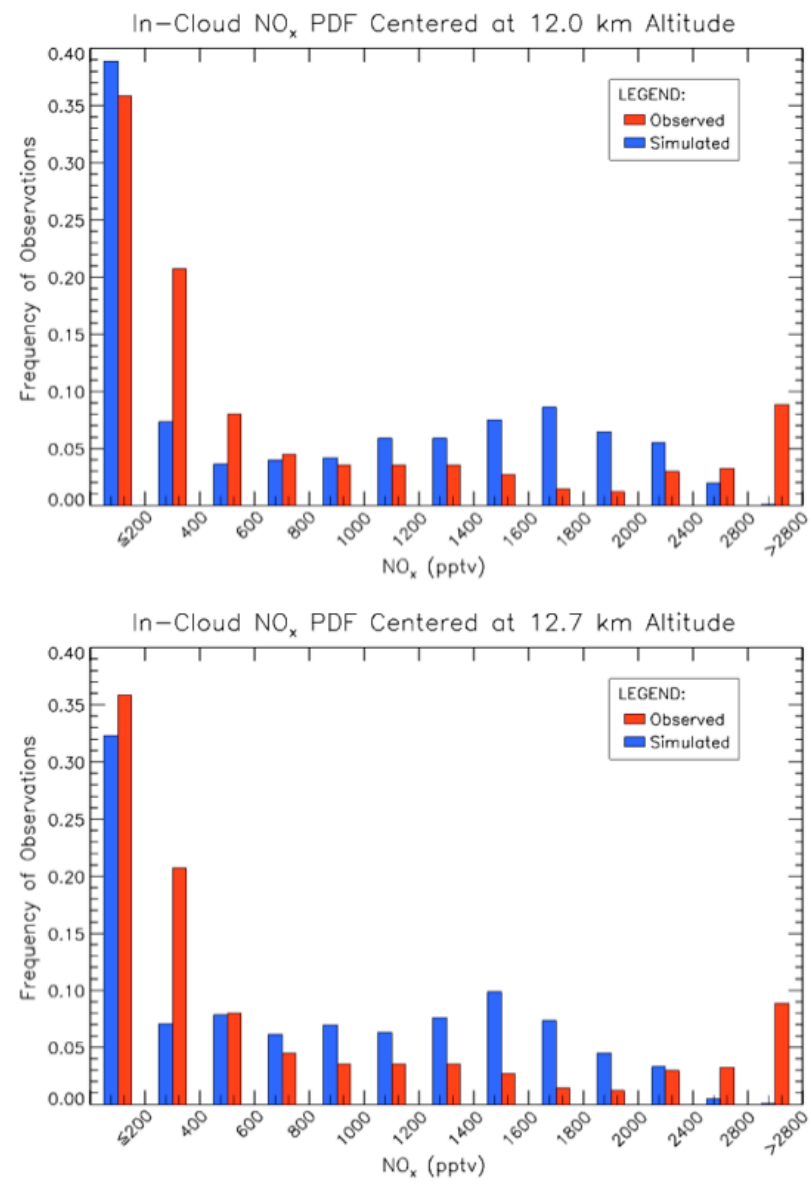

Fig. 15. PDF of $\mathrm{NO}_{\mathrm{x}}$ mixing ratios estimated from Egrett observations (red) and simulated (blue) in the model layer centered at $12.0 \mathrm{~km}$ and $12.7 \mathrm{~km}$ given 500 moles NO flash $^{-1}$. The Egrett observed $\mathrm{NO}_{\mathrm{x}}$ includes the directly measured $\mathrm{NO}_{\mathrm{x}}$ between 13.2$13.8 \mathrm{~km}$ and that estimated from the photostationary state when only one of $\mathrm{NO}$ or $\mathrm{NO}_{2}$ were available.

is significant, with wind direction turning from southeast to northwest with increasing height between the low- and upper-levels of the atmosphere, respectively (Fig. 3). This led to horizontal stretching of the storm system and possibly longer flash lengths than may be typical in the tropics. Hector, and other tropical island convection driven by localized surface heating, may create more powerful storms that are not representative of other types of tropical thunderstorms. This Hector storm, along with another Hector system documented by Huntrieser et al. (2009), indicate NO production per flash is larger than most other tropical thunderstorm events in the literature.

\subsection{Ozone}

Model $\mathrm{O}_{3}$ between 12:55-14:45 LT ranges from 6.6$18.6 \mathrm{ppbv}$ in the anvil model layer (centered at $13.4 \mathrm{~km}$ ) sampled by the Egrett due to both upward and downward trans-

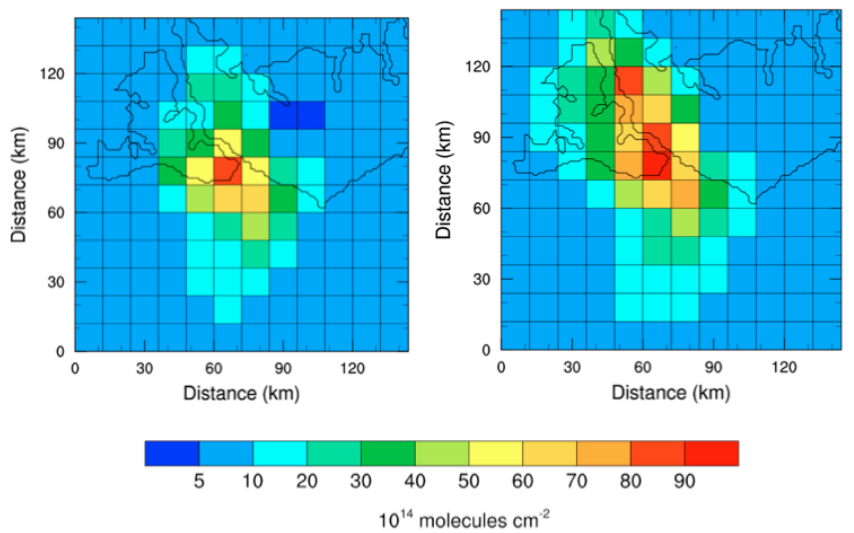

Fig. 16. Partial $\mathrm{NO}_{2}$ columns from the tropopause $(105 \mathrm{mb})$ to $400 \mathrm{mb}$ (left) and $600 \mathrm{mb}$ (right) for the simulated Hector thunderstorm at 14:45 LT. Each column covers $12 \times 12 \mathrm{~km}^{2}$ area. The tropopause height is estimated based on the idealized sounding and the climatological mean pressure of the lapse-rate tropopause from radiosonde data (Seidel et al., 2001).

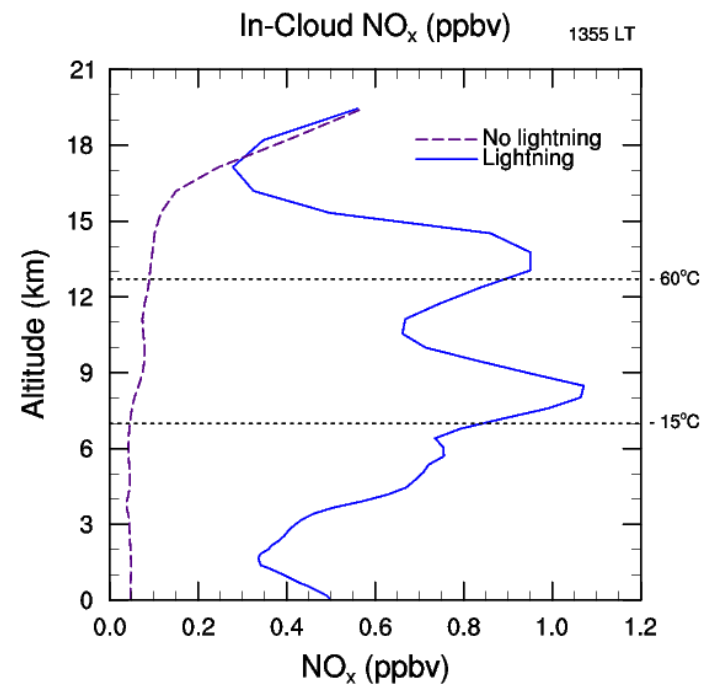

Fig. 17. Average in-cloud $\mathrm{NO}_{\mathrm{x}}$ at 13:55 LT for model simulations with and without lightning. Above $17.1 \mathrm{~km}$, values represent the average $\mathrm{NO}_{\mathrm{x}}$ directly above the cloud at $17.1 \mathrm{~km}$ for model simulations with and without lightning. The dashed lines at 7.0 and $12.7 \mathrm{~km}$ represent the usual altitude of the isotherms used for the lower and upper modes, respectively, of the vertical distribution of the lightning $\mathrm{NO}_{\mathrm{x}}$ source.

port, compared with the initial condition of $10 \mathrm{ppbv}$. Vertical cross sections of $\mathrm{O}_{3}$ mixing ratios for simulations without and with lightning (Fig. 19) show the upward and downward movement of $\mathrm{O}_{3}$ within the storm at 13:35 LT, a time of peak anvil $\mathrm{NO}_{\mathrm{x}}$ production within the model layers centered between $12.0-13.4 \mathrm{~km}$. The vertical cross section with lightning shows $\mathrm{O}_{3}$ mixing ratios are $\sim 4$ ppbv lower between $6-15 \mathrm{~km}$ in the storm core when compared with the 


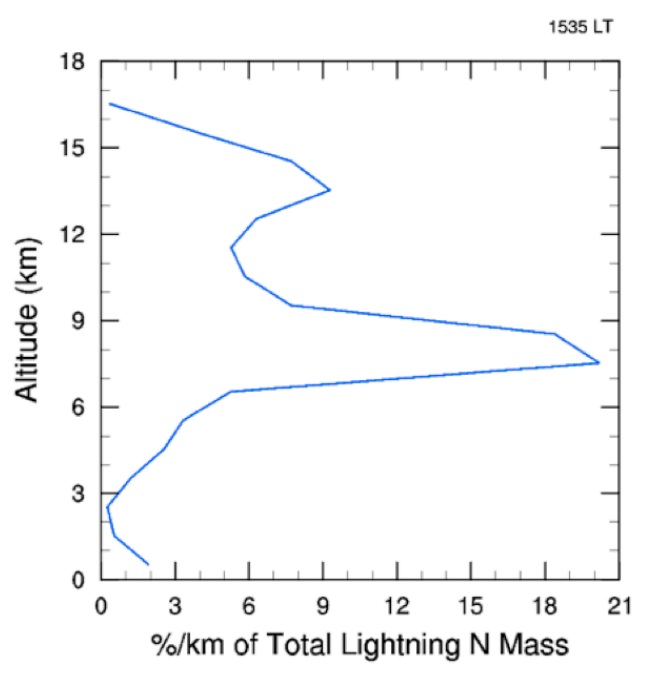

Fig. 18. Vertical distribution of percentage of lightning $\mathrm{NO}_{\mathrm{x}}$ mass per kilometer following convection at 15:35 LT given 500 moles NO flash $^{-1}$.

vertical cross section without lightning. Substantially larger $\mathrm{NO}_{\mathrm{x}}$ mixing ratios are produced by simulations run with versus without lightning (Figs. 12-13), suggesting $\mathrm{LNO}_{\mathrm{x}}$ had a role in $\mathrm{O}_{3}$ titration in the cloud. This effect had also been noted in previous research (Wang and Prinn, 2000; Ott et al., 2007). A comparison to observations cannot be performed at the $12.0 \mathrm{~km}$ and $12.7 \mathrm{~km}$ altitudes, as the Egrett did not measure $\mathrm{O}_{3}$ on this flight. The upward transport of low $\mathrm{O}_{3}$ from the lower troposphere and titration of $\mathrm{O}_{3}$ by $\mathrm{LNO}_{\mathrm{x}}$ decreases the $\mathrm{O}_{3}$ baseline in the upper troposphere prior to the initiation of downwind $\mathrm{O}_{3}$ production. It is desired to determine how much $\mathrm{O}_{3}$ is produced downwind of a thunderstorm following convection, however, our Hector simulation did not run past the end of the storm. Therefore, we can only provide the start of an answer concerning the overall impact of this storm on $\mathrm{O}_{3}$, especially when $\mathrm{O}_{3}$ production most likely started after the end of the simulation.

\section{Conclusions}

The 3-D WRF-AqChem model produces an idealized Hector storm with many characteristics similar to those observed. Cloud top height, horizontal dimensions of the convective cell and anvil, and peak radar reflectivity are roughly within $3 \%, 17 \%$, and $8 \%$ of the observations, respectively. Generally, the Hector storm evolution in the model is $2 \mathrm{~h}$ ahead of the observed storm. Mean anvil-level simulated $\mathrm{CO}$ and $\mathrm{NO}_{\mathrm{x}}$, when a lightning $\mathrm{NO}$ production scenario of 500 moles NO flash $^{-1}$ is used, compare well with Egrett observations, although the results for $\mathrm{CO}$ show a small overestimate in upward convective transport to anvil levels. However, this transport overestimate, uncertainty in the placement of the upper mode for IC $\mathrm{LNO}_{\mathrm{x}}$ production, and the lack

\section{Modeled $\mathrm{O}_{3}$ Mixing Ratios (ppbv)}

a) Without lightning

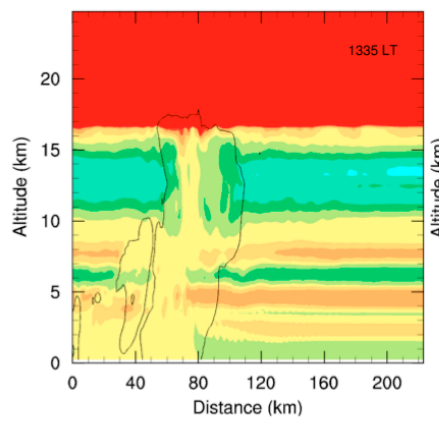

b) With lightning

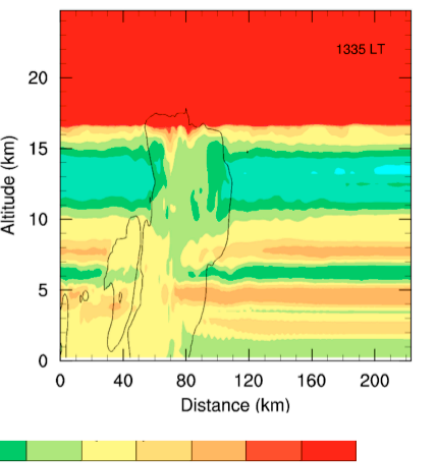

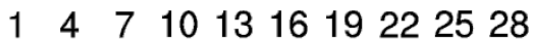

Fig. 19. Vertical cross sections of $\mathrm{O}_{3}$ mixing ratios, oriented $130^{\circ}$ from north through the storm core, for simulations (a) without and (b) with lightning NO production. The cross sections occur during a peak in average $\mathrm{NO}_{\mathrm{x}}$ production within the layers centered at $12.0 \mathrm{~km}$ and $12.7 \mathrm{~km}$. The thin black line indicates the $0.01 \mathrm{~g} \mathrm{~kg}^{-1}$ total condensate contour.

of Egrett anvil observations in more than one model layer, led to the possibility that $\mathrm{LNO}_{\mathrm{x}}$ production per flash could have been as large as 600 moles. Future improvements to the $\mathrm{LNO}_{\mathrm{x}}$ parameterization to inject the $\mathrm{NO}_{\mathrm{x}}$ for individual flashes along specific channels would likely improve the simulated $\mathrm{NO}_{\mathrm{x}}$ frequency distribution in the anvil. The Geophysica $\mathrm{NO}_{\mathrm{x}}$ observations suggest the upper tropospheric peak in lightning channel segments may occur 1-3 km higher in altitude than assumed in the model. Approximately $85 \%$ of the total $\mathrm{LNO}_{\mathrm{x}}$ mass resided above $7 \mathrm{~km}$ in the later stages of the storm. Small decreases in $\mathrm{O}_{3}$ in the region of peak lightning NO production are noted, likely from chemical loss involving titration by fresh NO emissions.

The mean NO production per flash for midlatitude and subtropical events previously studied with a similar approach is roughly equivalent to the results presented for this Hector storm. Analyses of aircraft $\mathrm{NO}_{\mathrm{x}}$ observations and flash data from other tropical regions (e.g., Brazil, West Africa) suggest smaller NO production per flash in the tropics than in midlatitudes (Huntrieser et al., 2008; Huntrieser et al., 2011). Aircraft observations of another Hector storm from SCOUTO3/ACTIVE also showed larger $\mathrm{NO}_{\mathrm{x}}$ production per flash than in other tropical events. The upper tropospheric column $\mathrm{NO}_{2}$ computed from the Hector simulation is of similar magnitude to that computed from midlatitude and subtropical simulations (Ott et al., 2010) and greater than in the tropical marine events observed by OMI (Bucsela et al., 2010). Therefore, we conclude that Hector, and other tropical island convection, may not be representative of other types of tropical thunderstorms. The wind velocity difference between the anvil outflow and steering level of the Hector storm was less 
than for most midlatitude storms, but the directional difference was significant in Hector, which could lead to enhanced flash length. However, additional research is required to further assess the Huntrieser et al. (2008) hypothesis that more $\mathrm{LNO}_{\mathrm{x}}$ may be produced per stroke in storms with greater wind shear.

Acknowledgements. This research was supported under NASA Aura Validation Program funding provided to Kenneth Pickering. The National Center for Atmospheric Research is supported by the National Science Foundation. The ACTIVE project was supported by the UK Natural Environment Research Council, grant NE/C512688/1 and directed by Geraint Vaughan of the University of Manchester. The authors would like to thank Heidi Huntrieser from Deutsches Zentrum für Luft- und Raumfahrt and two anonymous reviewers for their comments.

Edited by: H. Tost

\section{References}

Allen, G., Vaughan, G., Bower, K. N., Williams, P. I., Crosier, J., Flynn, M., Connolly, P., Hamilton, J. F., Lee, J. D., Saxton, J. E., Watson, N. M., Gallagher, M., Coe, H., Allan, J., Choularton, T. W., and Lewis, A. C.: Aerosol and trace-gas measurements in the Darwin area during the wet season, J. Geophys. Res., 113, D06306, doi:10.1029/2007JD008706, 2008.

Barth, M. C., Kim, S.-W., Skamarock, W. C., Stuart, A. L., Pickering, K. E., and Ott, L. E.: Simulations of the redistribution of formaldehyde, formic acid, and peroxides in the 10 July 1996 Stratospheric-Tropospheric Experiment: Radiation, Aerosols, and Ozone deep convection storm, J. Geophys. Res., 112, D13310, doi:10.1029/2006JD008046, 2007a.

Barth, M. C., Kim, S.-W., Wang, C., Pickering, K. E., Ott, L. E., Stenchikov, G., Leriche, M., Cautenet, S., Pinty, J.-P., Barthe, Ch., Mari, C., Helsdon, J. H., Farley, R. D., Fridlind, A. M., Ackerman, A. S., Spiridonov, V., and Telenta, B.: Cloud-scale model intercomparison of chemical constituent transport in deep convection, Atmos. Chem. Phys., 7, 4709-4731, doi:10.5194/acp-74709-2007, 2007b.

Barthe, C. and Barth, M. C.: Evaluation of a new lightningproduced $\mathrm{NO}_{\mathrm{x}}$ parameterization for cloud resolving models and its associated uncertainties, Atmos. Chem. Phys., 8, 4691-4710, doi:10.5194/acp-8-4691-2008, 2008.

Barthe, C., Pinty, J.-P., and Mari, C.: Lightning-produced $\mathrm{NO}_{\mathrm{x}}$ in an explicit electrical scheme tested in a Stratosphere-Troposphere Experiment: Radiation, Aerosols, and Ozone case study, J. Geophys. Res., 112, D04302, doi:10.1029/2006JD007402, 2007.

Barthe, C., Deierling, W., and Barth, M. C.: Estimation of total lightning from various storm parameters: A cloudresolving model study, J. Geophys. Res., 115, D24202, doi:10.1029/2010JD014405, 2010.

Beirle, S., Salzmann, M., Lawrence, M. G., and Wagner, T.: Sensitivity of satellite observations for freshly produced lightning $\mathrm{NO}_{\mathrm{x}}$, Atmos. Chem. Phys., 9, 1077-1094, doi:10.5194/acp-91077-2009, 2009.
Beirle, S., Huntrieser, H., and Wagner, T.: Direct satellite observation of lightning-produced $\mathrm{NO}_{\mathrm{x}}$, Atmos. Chem. Phys., 10, 10965-10986, doi:10.5194/acp-10-10965-2010, 2010.

Betz, H.-D., Schmidt, K., Oettinger, W. P., and Wirz, M.: Lightning detection with 3D-discrimination of intracloud and cloud-to-ground discharges, Geophys. Res. Lett., 31, L11108, doi:10.1029/2004GL019821, 2004.

Betz, H.-D., Schmidt, K., Fuchs, B., Oettinger, W. P., and Höller, H.: Cloud lightning: Detection and utilization for total lightning measured in the VLF/LF regime, J. Lightning Res., 2, 1-17, 2007.

Betz, H.-D., Schmidt, K., and Oettinger, W. P.: LINET - An International VLF/LF Lightning Detection Network in Europe, in: Lightning: Principles, Instruments and Applications, edited by: Betz, H.-D., Schumann, U., and Laroche, P., Springer, Dordrecht (NL), Ch. 5, 2008.

Boersma, K. F., Eskes, H. J., Meijer, E. W., and Kelder, H. M.: Estimates of lightning $\mathrm{NO}_{\mathrm{x}}$ production from GOME satellite observations, Atmos. Chem. Phys., 5, 2311-2331, doi:10.5194/acp-52311-2005, 2005.

Brunner, D., Siegmund, P., May, P. T., Chappel, L., Schiller, C., Müller, R., Peter, T., Fueglistaler, S., MacKenzie, A. R., Fix, A., Schlager, H., Allen, G., Fjaeraa, A. M., Streibel, M., and Harris, N. R. P.: The SCOUT-O3 Darwin Aircraft Campaign: rationale and meteorology, Atmos. Chem. Phys., 9, 93-117, doi:10.5194/acp-9-93-2009, 2009.

Bucsela, E. J., Pickering, K. E., Huntemann, T. L., Cohen, R. C., Perring, A., Gleason, J. F., Blakeslee, R. J., Albrecht, R. I., Holzworth, R., Cipriani., J. P., Vargar-Navarro, D., MoraSegura, I., Pacheco-Hernandez, A., and Laporte-Molina, S.: Lightning-generated $\mathrm{NO}_{\mathrm{x}}$ seen by the Ozone Monitoring Instrument during NASA's Tropical Composition, Cloud and Climate Coupling Experiment $\left(\mathrm{TC}^{4}\right)$, J. Geophys. Res., 115, D00J10, doi:10.1029/2009JD013118, 2010.

Carbone, R. E., Keenan, T. D., Hacker, J., and Wilson, J. W.: Tropical island convection in the absence of significant topography. Part I: Life cycle of diurnally forced convection, Mon. Weather Rev., 128, 3459-3480, 2000.

Chatfield, R. B. and Crutzen, P. J.: Sulfur dioxide in remote ocean air: Cloud transport of reactive precursors, J. Geophys. Res., 89, 7111-7132, 1984.

Chemel, C., Russo, M. R., Pyle, J. A., Sokhi, R. S., and Schiller, C.: Quantifying the imprint of a severe Hector thunderstorm during ACTIVE/SCOUT-O3 onto the water content in the upper troposphere/lower stratosphere, Mon. Weather Rev., 137, 2493-2514, doi:10.1175/2008MWR2666.1, 2009.

Crook, N. A.: Understanding Hector: the dynamics of island thunderstorms, Mon. Weather Rev., 129, 1550-1563, 2001.

Dahl, J. M. L., Höller, H., and Schumann, U.: Modeling the flash rate of thunderstorms. Part I: Framework, Mon. Weather Rev., 139, 3093-3111, doi:10.1175/MWR-D-10-05031.1, 2011a.

Dahl, J. M. L., Höller, H., and Schumann, U.: Modeling the flash rate of thunderstorms. Part II: Implementation, Mon. Weather Rev., 139, 3112-3124, doi:10.1175/MWR-D-1005032.1, 2011b.

DeCaria, A. J., Pickering, K. E., Stenchikov, G. L., Scala, J. R., Stith, J. L., Due, J. E., Ridley, B. A., and Laroce, P.: A cloudscale model study of lightning-generated $\mathrm{NO}_{\mathrm{x}}$ in an individual thunderstorm during STERAO-A, J. Geophys. Res., 105, 
11601-11616, 2000.

DeCaria, A. J., Pickering, K. E., Stenchikov, G. L., and Ott, L. E.: Lightning-generated $\mathrm{NO}_{\mathrm{x}}$ and its impact on tropospheric ozone production: A 3-D modeling study of a STERAO-A thunderstorm, J. Geophys. Res., 110, D14303, doi:10.1029/2004JD005556, 2005.

Deierling, W. and Petersen, W. A.: Total lightning activity as an indicator of updraft characteristics, J. Geophys. Res., 113, D16210, doi:10.1029/2007JD009598, 2008.

Deierling, W., Petersen, W. A., Latham, J., Ellis, S., and Christian, H. J.: The relationship between lightning activity and ice fluxes in thunderstorms, J. Geophys. Res., 113, D15210, doi:10.1029/2007JD009700, 2008.

Dickerson, R. R., Huffman, G. J., Luke, W. T., Nunnermacker, L. J., Pickering, K. E., Leslie, A. C. D., Lindsey, C. G., Slinn, W. G. N., Kelly, T. J., Daum, P. H., Delany, A. C., Greenberg, J. P., Zimmerman, P. R., Boatman, J. F., Ray, J. D., and Steadman, D. H.: Thunderstorms: An important mechanism in the transport of air pollutants, Science, 235, 460-465, 1987.

Fehr, T., Höller, H., and Huntrieser, H.: Model study on production and transport of lightning-produced $\mathrm{NO}_{\mathrm{x}}$ in a EULINOX supercell storm, J. Geophys. Res., 109, D09102, doi:10.1029/2003JD003935, 2004.

Golding, B. W.: A numerical investigation of tropical island thunderstorms, Mon. Wea. Rev., 121, 1417-1433, 1993.

Höller, H., Betz, H.-D., Schmidt, K., Calheiros, R. V., May, P., Houngninou, E., and Scialom, G.: Lightning characteristics observed by a VLF/LF lightning detection network (LINET) in Brazil, Australia, Africa and Germany, Atmos. Chem. Phys., 9, 7795-7824, doi:10.5194/acp-9-7795-2009, 2009.

Huntrieser, H., Schlager, H., Roiger, A., Lichtenstern, M., Schumann, U., Kurz, C., Brunner, D., Schwierz, C., Richter, A., and Stohl, A.: Lightning-produced $\mathrm{NO}_{\mathrm{x}}$ over Brazil during TROCCINOX: airborne measurements in tropical and subtropical thunderstorms and the importance of mesoscale convective systems, Atmos. Chem. Phys., 7, 2987-3013, doi:10.5194/acp-7-29872007, 2007.

Huntrieser, H., Schumann, U., Schlager, H., Höller, H., Giez, A., Betz, H.-D., Brunner, D., Forster, C., Pinto Jr., O., and Calheiros, R.: Lightning activity in Brazilian thunderstorms during TROCCINOX: implications for $\mathrm{NO}_{\mathrm{x}}$ production, Atmos. Chem. Phys., 8, 921-953, doi:10.5194/acp-8-921-2008, 2008.

Huntrieser, H., Schlager, H., Lichtenstern, M., Roiger, A., Stock, P., Minikin, A., Höller, H., Schmidt, K., Betz, H.-D., Allen, G., Viciani, S., Ulanovsky, A., Ravegnani, F., and Brunner, D.: $\mathrm{NO}_{\mathrm{x}}$ production by lightning in Hector: first airborne measurements during SCOUT-O3/ACTIVE, Atmos. Chem. Phys., 9, 83778412, doi:10.5194/acp-9-8377-2009, 2009.

Huntrieser, H., Schlager, H., Lichtenstern, M., Stock, P., Hamburger, T., Höller, H., Schmidt, K., Betz, H.-D., Ulanovsky, A., and Ravegnani, F.: Mesoscale convective systems observed during AMMA and their impact on the $\mathrm{NO}_{\mathrm{x}}$ and $\mathrm{O}_{3}$ budget over West Africa, Atmos. Chem. Phys., 11, 2503-2536, doi:10.5194/acp-11-2503-2011, 2011.

Isaac, P. and Hacker, J.: ACTIVE VH-ARA data set, ARA Technical Report, Airborne Research Australia/Finders University, Salisbury South, Australia, 106 pp., 2007.

IPCC: Climate Change 2007: The Physical Science Basis. Contribution of Working Group I to the Fourth Assessment Report of the Intergovernmental Panel on Climate Change, edited by: Solomon, S., Qin, D., Manning, M., Chen, Z., Marquis, M., Averyt, K. B., Tignor, M., and Miller, H. L., Cambridge, United Kingdom and New York, NY, USA, 996 pp., 2007.

Koike, M., Kondo, Y., Kita, K., Takegawa, N., Nishi, N., Kashihara, T., Kawakami, S., Kudoh, S., Blake, D., Shirai, T., Liley, B., Ko, M., Miyazaki, Y., Kawasaki, Z., and Ogawa, T.: Measurements of reactive nitrogen produced by tropical thunderstorms during BIBLE-C, J. Geophys. Res., 112, D18304, doi:10.1029/2006JD008193, 2007.

Kuhlman, K. M., MacGorman, D. R., Biggerstaff, M. I., and Krehbiel, P. R.: Lightning initiation in the anvils of two supercell storms, Geophys. Res. Lett., 36, L07802, doi:10.1029/2008GL036650, 2009.

Labrador, L. J., von Kuhlmann, R., and Lawrence, M. G.: The effects of lightning-produced $\mathrm{NO}_{\mathrm{x}}$ and its vertical distribution on atmospheric chemistry: sensitivity simulations with MATCHMPIC, Atmos. Chem. Phys., 5, 1815-1834, doi:10.5194/acp-51815-2005, 2005.

Labrador, L., Vaughan, G., Heyes, W., Waddicor, D., Volz-Thomas, A., Pätz, H.-W., and Höller, H.: Lightning-produced $\mathrm{NO}_{\mathrm{x}}$ during the Northern Australian monsoon; results from the ACTIVE campaign, Atmos. Chem. Phys., 9, 7419-7429, doi:10.5194/acp9-7419-2009, 2009.

Lang, S. E., Tao, W.-K., Zeng, X., and Li, Y.: Reducing the biases in simulated radar reflectivities from a bulk microphysics scheme: Tropical convective systems, J. Atmos. Sci., 68, 23062320, 2011.

Lin, Y.-L., Farley, R. D., and Orville, H. D.: Bulk parameterization of the snow field in a cloud model, J. Clim. Appl. Meteorol., 22, 1065-1092, 1983.

MacGorman, D. R. and Rust, W. D.: The Electrical Nature of Storms, Oxford Univ. Press, New York, 422 pp., 1998.

Madronich, S. and Flocke, S.: The role of solar radiation in atmospheric chemistry, in: Handbook of Environmental Chemistry, edited by: Boule, P., Springer, New York, 1-26, 1999.

May, P. T. and Ballinger, A.: The statistical characteristics of convective cells in a monsoon regime (Darwin, Northern Australia), Mon. Weather Rev., 135, 82-92, doi:10.1175/MWR3273.1, 2007.

Ott, L. E., Pickering, K. E., Stenchikov, G. L., Huntrieser, H., and Schumann, U.: Effects of lightning $\mathrm{NO}_{\mathrm{x}}$ production during the 21 July European Lightning Nitrogen Oxides Project storm studied with a three-dimensional cloudscale chemical transport model, J. Geophys. Res., 112, D05307, doi:10.1029/2006JD007365, 2007.

Ott, L. E., Pickering, K. E., Stenchikov, G. L., Allen, D. J., DeCaria, A. J., Ridley, B., Lin, R.-F., Wang, D., Lang, S., and Tao, W.-K.: Production of lightning $\mathrm{NO}_{\mathrm{x}}$ and its vertical distribution calculated from 3-D cloud-scale chemical transport model simulations, J. Geophys. Res., 115, D04301, doi:10.1029/2009JD011880, 2010.

Petersen, W. A., Christian, H. J., and Rutledge, S. A.: TRMM observations of the global relationship between ice water content and lightning, Geophys. Res. Lett., 32, L14819, doi:10.1029/2005GL023236, 2005.

Pickering, K. E., Thompson, A. M., Dickerson, R. R., Luke, W. T., and McNamara, D. P.: Model calculations of tropospheric ozone production potential following observed convective events, J. 
Geophys. Res., 95, 14049-14062, 1990.

Pickering, K. E., Thompson, A. M., Scala, J. R., Tao, W.-K., Dickerson, R. R., and Simpson, J.: Free tropospheric ozone production following entrainment of urban plumes into deep convection, J. Geophys. Res., 97, 17985-18000, 1992.

Pickering, K. E., Thompson, A. M., Tao, W., and Kucsera, T. L.: Upper tropospheric ozone production following mesoscale convection during STEP/EMEX, J. Geophys. Res., 98, 8737-8749, 1993.

Pickering, K. E., Wang, Y., Tao, W.-K., Price, C., and Müller, J.F.: Vertical distribution of lightning $\mathrm{NO}_{\mathrm{X}}$ for use in regional and global chemical transport models, J. Geophys. Res., 103, 3120331216, 1998.

Price, C. and Rind, D.: A simple lightning parameterization for calculating global lightning distributions, J. Geophys. Res., 97, 9919-9933, doi:10.1029/92JD00719, 1992.

Price, C. and Rind, D.: What determines the cloud-to-ground lightning fraction in thunderstorms?, Geophys. Res. Lett., 20, 463466, 1993.

Price, C., Penner, J., and Prather, M.: $\mathrm{NO}_{\mathrm{x}}$ from lightning 1. Global distribution based on lightning physics, J. Geophys. Res., 102, 5929-5941, 1997.

Saito, K., Keenan, T., Holland, G., and Puri, K.: Numerical simulation of the diurnal evolution of tropical island convection over the Maritime Continent, Mon. Weather Rev., 129, 378-400, 2001.

Salzmann, M., Lawrence, M. G., Phillips, V. T. J., and Donner, L. J.: Cloud system resolving model study of the roles of deep convection for photo-chemistry in the TOGA COARE/CEPEX region, Atmos. Chem. Phys., 8, 2741-2757, doi:10.5194/acp-82741-2008, 2008.
Schumann, U. and Huntrieser, H.: The global lightning-induced nitrogen oxides source, Atmos. Chem. Phys., 7, 3823-3907, doi:10.5194/acp-7-3823-2007, 2007.

Seidel, D. J., Ross, R. J., Angell, J. K., and Reid, G. C.: Climatological characteristics of the tropical tropopause as revealed by radiosondes, J. Geophys. Res., 106, 7857-7878, doi:10.1029/2000JD900837, 2001.

Skamarock, W. C., Klemp, J. B., Dudhia, J., Gill, D., Barker, D., Wang, W., and Powers, J. G.: A description of the Advanced Research WRF Version 2., Technical Note NCAR/TN-468+STR, NCAR, Boulder, Colorado, 2005.

Vaughan, G., Schiller, C., MacKenzie, A. R., Bower, K., Peter, T., Schlager, H., Harris, N. R. P., and May, P. T.: SCOUTO3/ACTIVE: High-altitude aircraft measurements around deep tropical convection, B. Am. Meteorol. Soc., 89, 647-662, 2008.

Wang, C. and Prinn, R.: On the roles of deep convective clouds in tropospheric chemistry, J. Geophys. Res., 105, 22269-22298, 2000.

Zhang, X., Helsdon Jr., J. H., and Farley, R. D.: Numerical modeling of lightning-produced $\mathrm{NO}_{\mathrm{x}}$ using an explicit lightning scheme: 1 . Two-dimensional simulation as a "proof of concept", J. Geophys. Res., 108, 4579, doi:10.1029/2002JD003224, 2003a.

Zhang, X., Helsdon Jr., J. H., and Farley, R. D.: Numerical modeling of lightning-produced $\mathrm{NO}_{\mathrm{X}}$ using an explicit lightning scheme: 2 . Three-dimensional simulation and expanded chemistry, J. Geophys. Res., 108, 4580, doi:10.1029/2002JD003225, 2003 b. 